Document downloaded from:

http://hdl.handle.net/10251/63155

This paper must be cited as:

Acosta-Quezada, P.; Martinez-Laborde, J.; Prohens Tomás, J. (2011). Variation among tree tomato (Solanum betaceum Cav.) accessions from different cultivar groups: implications for conservation of genetic resources and breeding. Genetic Resources and Crop Evolution. 58(6):943-960. doi:10.1007/s10722-010-9634-9.

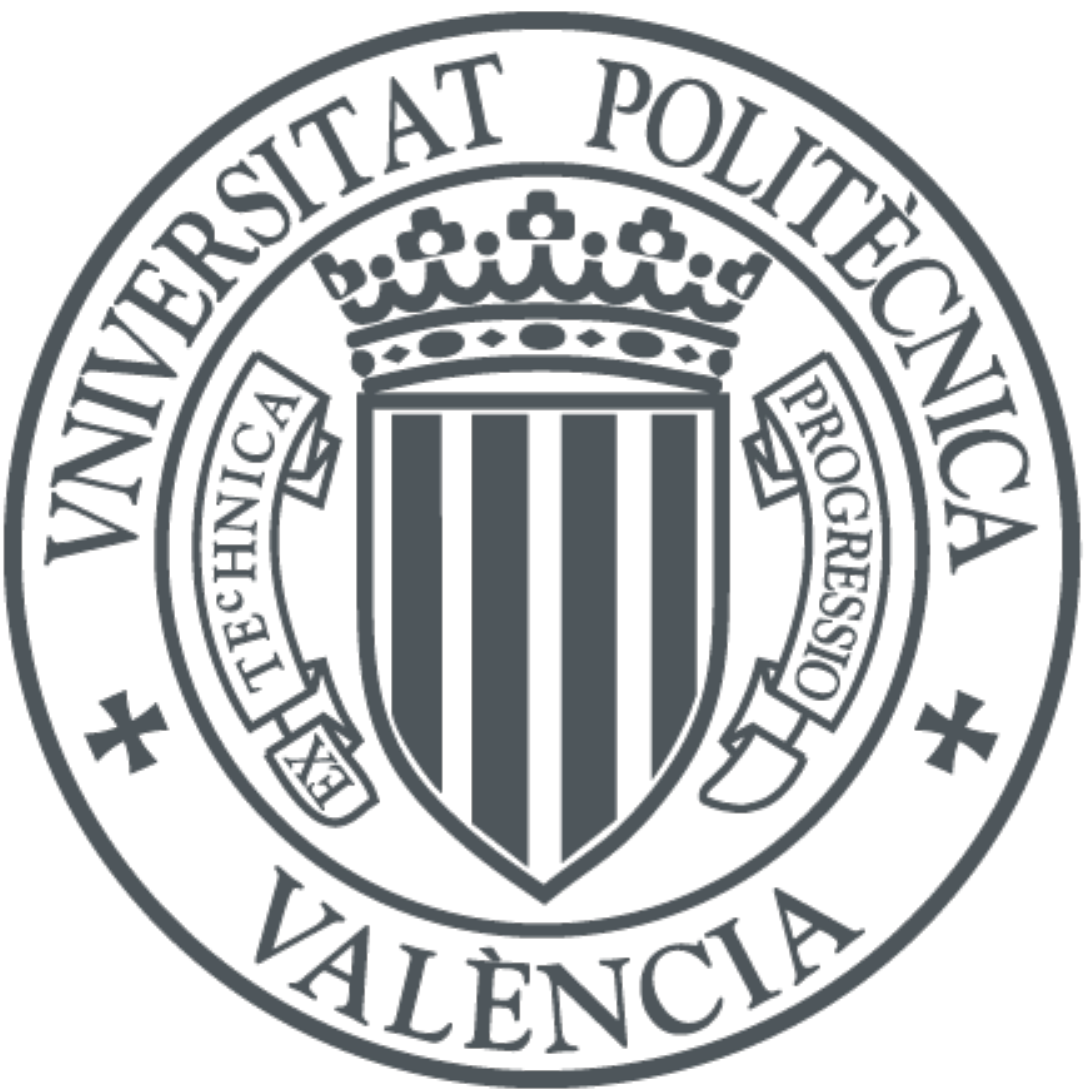

The final publication is available at

http://dx.doi.org/10.1007/s10722-010-9634-9

Copyright Springer Verlag (Germany)

Additional Information 


\title{
Variation among tree tomato (Solanum betaceum Cav.) accessions from different cultivar groups: implications for conservation of genetic resources and breeding
}

Pablo G. Acosta-Quezada ${ }^{1}$, Juan B. Martínez-Laborde ${ }^{2}$, Jaime Prohens ${ }^{3}$

${ }^{1}$ Centro de Investigación, Transferencia de Tecnología, Extensión y Servicios Agropecuarios, Universidad Técnica Particular de Loja, San Cayetano Alto s/n, 1101608 Loja, Ecuador

${ }^{2}$ Departamento de Biología Vegetal, Escuela Técnica Superior de Ingenieros Agrónomos, Universidad Politécnica de Madrid, Av. Complutense 3, Ciudad Universitaria, 28040 Madrid, Spain

${ }^{3}$ Instituto de Conservación y Mejora de la Agrodiversidad Valenciana, Universidad Politécnica de Valencia, Camino de Vera 14, 46022 Valencia, Spain

\begin{abstract}
Tree tomato (Solanum betaceum, Solanaceae) is a neglected small tree native to the Andean region used for its edible and juicy fruits. We have elaborated a list of 39 quantitative morphological descriptors for different plant parts (plant architecture, leaf, inflorescence and flower, infructescence and fruit, and seed) and have used them to characterize 24 accessions of tree tomato from different origins corresponding to five cultivar groups: orange, orange pointed, purple, red, and red conical. Several parameters, including range, maximum/minimum value ratio, standard deviation, coefficient of variation, and broad-sense heritability, as well as analyses of variance, have been used to validate the utility of the descriptors, which have proved useful for the characterization of this crop. Significant $(\mathrm{P}<0.05)$ differences among accessions were found for the descriptors we evaluated, with the exception of three flower-size
\end{abstract}


descriptors. Fruit and infructescence traits and seed number displayed the most variation and greatest heritability values. Considerable variation was found within each cultivar group for many traits. Many differences were found at the morphological level between the odd, red conical group, which includes a single accession with small fruits containing very few seeds, and all other cultivar groups. Ranges of variation among these other groups overlap for most of the descriptors studied, although the orange and red cultivar groups are the most distinct. Most of the significant correlations found among traits connect descriptors from the same part of the plant. Multivariate cluster and principal component analyses separated the tree tomato accessions into several morphologically similar groups. With the exception of single accession clusters, the rest of clusters contain accessions of several cultivar groups, reflecting considerable variation within cultivar groups, as well as (with the exception of the red conical group) a low degree of morphological differentiation among them. The descriptors we developed and the results obtained are relevant for the conservation and breeding of this promising fruit crop.

Keywords: correlations, descriptors, heritability, morphological characterization, multivariate analysis

\section{Introduction}

Tree tomato or tamarillo (Solanum betaceum Cav., syn. Cyphomandra betacea (Cav.) Sendtn., Solanaceae) is a small tree native to the Andean region of Bolivia (Bohs 1991; Bohs and Nelson 1997; Lester and Hawkes, 2001). It is cultivated in for its fleshy 
edible fruits, which can be consumed raw, mostly for preparing juices, processed, or cooked (Bohs 1989a; Prohens and Nuez 2000). In the Andean region, tree tomato is locally important and has engendered great interest for both domestic and international markets, but it still remains a marginal crop (Hernández-Bermejo and León 1992). At present, it is mainly grown on subsistence farms and is generally neglected in research and conservation programmes. Tree tomato represents an alternative crop for agricultural diversification, as well as for non-traditional commodity production and marketing, in its region of origin as well as in other countries. In this respect, it has aroused remarkable interest in New Zealand -the world's largest tree tomato produceras a "new crop." It is also a promising crop for some Mediterranean countries, including Spain and Italy (Pileri 1989; Boyes and Strübi 1997; Prohens and Nuez 2000; Prohens et al. 2004).

Tree tomato and its relatives were formerly included in genus Cyphomandra, but were transferred to Solanum by Bohs (1995). The taxonomy, biosystematics, phylogeny, and ethnobotany of tree tomato and its wild relatives have been extensively studied by Bohs (1989a, 1989b, 1991, 1994, 1995, 2001, 2007) and co-workers (Bohs and Nelson 1997; Bohs and Olmstead 1997; Weese and Bohs 2007). However, very little research on the diversity and characterization of genetic resources of S. betaceum has been published (Enciso-Rodríguez et al. 2010). Similarly, very few works have been devoted to the genetic improvement of tree tomato (Pringle and Murray 1991a, 1992a, 1992b). On the other hand, studies of the chemical composition and post-harvest performance of tree tomato fruits have recently been conducted (Mwithiga et al. 2007; Mertz et al. 2009; Vasco et al. 2009), but we have found no attempts to characterize the morphological diversity of this species. In this respect, the establishment of cultivar groups is a keydevelopment that can enhance the utilization and conservation of genetic 
resources (Spooner et al. 2003). However, there are no clear rules for classifying tree tomato accessions into established cultivar groups or for creating new groups. Although on most occasions tree tomato accessions have been grouped by fruit colour, mostly into orange, red, and purple cultivar groups (National Research Council 1989; Bohs 1994; Prohens and Nuez 2000), for farmers, dealers, and consumers, other characteristics, such as fruit shape, are also important.

Characterization of germplasm is essential to maximize its utility (DayRubenstein et al. 2006) and foster efficient ex situ conservation (Hammer et al. 2003; de Vicente et al. 2006). Morphological and agronomic characterization has been widely used to assess phenotypic variation of other Solanum crops, such as tomato (Solanum lycopersicum L.), potato (Solanum tuberosum L.), eggplant (Solanum melongena L.), and pepino (Solanum muricatum Aiton) (Huamán and Spooner 2002; RodríguezBurruezo et al. 2002; Muñoz-Falcón et al. 2008; Kwon et al. 2009). The evaluation of morphological and agronomic characters can provide relevant information on yield and quality traits, as well as other information of great interest to horticulturists and breeders, such as descriptions of available variation and estimates of trait heritability. For an optimal characterization of genetic resources and for valid data comparisons among trials, it is necessary to use standard descriptors, like those developed by Bioversity International for other Solanum crops used for their fruits (e.g., IBPGR 1990; IPGRI 1996, 2004). However, internationally standardized morphological descriptors do not exist for tree tomato.

We have studied morphological variation and relationships in accessions of Solanum betaceum supplied by two genebanks. Most accessions were collected from the Andean region of South America, where the species originated (Bohs 1991; Bohs 
and Nelson 1997). To conduct this study, we established morphological descriptors that could serve as the basis for a future standardized tree tomato descriptor list.

\section{Material and methods}

\section{Plant material}

Seed samples of 24 accessions of cultivated tree tomato, originally collected in six countries, were provided for this study by the genebanks of the Universidad Técnica Particular de Loja (UTPL) in Ecuador and the Universidad Politécnica de Valencia (UPV) in Spain (Table 1). Accessions were selected to represent a diversity of morphological types and origins. On the basis of the genebanks' description of these accessions, fruit characteristics (mostly fruit apex shape, fruit color, and seed-mucilage color), and farmers' grouping of cultivars, accessions were assigned to five tentative cultivar groups: orange, orange pointed, purple, red, and red conical (National Research Council, 1989; Bohs 1994; Prohens and Nuez, 2000). These five cultivar groups of tree tomato are considered as different by the farmers and dealers. Some of the cultivar groups studied, like the orange pointed, are very frequent and contain many accessions, while others like the red conical are hardly found in commercial plantations and markets, and consist of a single accession.

\section{Plant cultivation}

Seeds were sown in plastic bags containing a 3:2:1 mixture of organic soil:sand:earthworm humus and seedlings transplanted in October 2007 (40 to 50 days after germination) to a UTPL field plot located in Loja, Ecuador ( $4^{\circ} 0^{\prime} 1.59^{\prime \prime} \mathrm{S}$ and $79^{\circ}$ $10^{\prime} 48.46 " \mathrm{~W}$ ) at 2160 masl. The area corresponds to the low dry montane forest (bs- 
MB) formation (Holdridge 1967), with $15.4^{\circ} \mathrm{C}$ mean annual temperature and mean annual rainfall of $780 \mathrm{~mm}$. The soil of the plot is clay loam. Planting was made into $0.4 \times 0.4 \times 0.4 \mathrm{~m}$ holes, each one previously enriched with $4 \mathrm{~kg}$ of earthworm humus and $300 \mathrm{~g}$ of $12-36-12\left(\mathrm{~N}-\mathrm{P}_{2} \mathrm{O}_{5}-\mathrm{K}_{2} \mathrm{O}\right)$ fertilizer, by using a $2 \times 2 \mathrm{~m}$ planting distance. Plants were treated when necessary against pests (Myzus aphids). Preventive fungicidal treatments against Phytophthora infestans, Colletotrichum gloeosporioides, and Oidium sp. were also administered. Plants were mounded several times for better plant support and weed control.

\section{Morphological characterization}

Given that no standard descriptors for morphological characterization were available for this crop, we elaborated a set of descriptors for quantitative traits. These descriptors were developed on the basis of morphological descriptors for several other Solanaceae, published by Bioversity International (http://www.bioversityinternational.org/publications), and of the authors' own experience in the development of Solanum descriptors (e.g., IPGRI 2004; Prohens et al. 2005) and the characterization of tree tomato (Prohens et al. 1996; Prohens and Nuez 2000). Descriptor dvelopment accounted for the utility of descriptors for breeders and curators of germplasm collections, the description of different plant parts, the evaluation of observed variation, and efficient data acquisition. A total of 39 descriptors, which correspond to different plant characteristics and parts, including leaves, flowers and inflorescences, fruits and infructescences, and seeds, and overall architecture have been established (Table 2). 
Twenty four plants per accession were arranged in a randomized complete block design, with three blocks and eight replications (one plant=one replication) per block. Fifteen randomly selected representative plants per accession (five per block) were evaluated. The number of samples evaluated per accession, with an equivalent number of measurements taken from each plant, was: 15 for whole-plant traits and inflorescence traits (except inflorescence rachis internode length), 30 for leaf and inflorescence rachis internode length, 75 for flower (except petal length and width) and fruit traits, and for seeds per fruit, 150 for seed size, and 375 for petal length and width. Samples for a given descriptor were evaluated on the same day, when appropriate, during the period from January 2008 to July 2009.

\section{Data analysis}

For each descriptor, we calculated the following parameters: mean, maximum value, minimum value, range, maximum value/minimum value ratio, standard deviation (SD), coefficient of variation (CV) and broad-sense heritability $\left(H^{2}\right)$ (Dabholkar 1992). Data were also subjected to analysis of variance (ANOVA) tests and, where significant $(\mathrm{P}<0.05)$ differences were observed among accessions, means were separated by the Student-Newman-Keuls multiple range test. Pearson linear coefficients of correlation (r) were calculated from non-parametric regression analyses between pairs of descriptors, and significance of correlations was evaluated with the Bonferroni test (Hochberg 1988). A Euclidean distance matrix based on standarized data was computed for clustering analysis by using the UPGMA (Unweighted Pair Group Method with Arithmetic Mean) method (Sneath and Sokal 1973; Mohammadi and Prasanna 2003). Goodness of fit of the resulting dendrogram was evaluated with the cophenetic correlation coefficient by using the Mantel (1967) test. For principal component 
analysis (PCA), a character correlation matrix was computed from standardized values and Pearson's correlation coefficient. ANOVA tests were performed with Statgraphics Plus 5.1 software (Statistical Graphics Corp., Rockville, MD, USA) and correlation and multivariate analyses with NTSYS-pc 2.0 software (Applied Biostatistics Inc., Setauket, NY, USA).

\section{Results}

\section{Descriptors development}

As described above, we developed 39 quantitative descriptors for tree tomato (Table 2). Measurements of most of these descriptors can be done directly in the field with appropriate equipment, although for some flower, fruit, and seed descriptors it is necessary to bring samples to the laboratory. Also, certain leaf descriptors can be more easily measured in the laboratory by using image-processing tools, like the UTHSCSA Image Tool (University of Texas Health Science Center, San Antonio, Texas, USA) software, which was used to take leaf size measurements using scanned images . In total, we evaluated four descriptors for plant architecture (C1-C4), thirteen descriptors for leaves (C5-C17) (Figure 1), eight descriptors for inflorescences and flowers (C18C25), eleven descriptors for infructescences and fruits (C26-C36), , and three descriptors (C37-C39) for seeds (Table 2). For all descriptors developed, measurements were easy to obtain and readily taken by technical staff trained in genetic resource management.

\section{Descriptors validation}


Values for the different parameters we studied are presented in Table 3. Considerable differences were found for the maximum and minimum values for many descriptors, which resulted in wide variation among accessions. The fact that stem leaves and crown leaves present considerable morphological differences in our measurement data (Table 3) justifies having different descriptors for both types of leaves.

The highest maximum value/minimum value ratios (i.e., those with higher relative ranges of variation) included the number of seeds per fruit (C39) with a ratio of 112.40, resulting from a range of variation from 3.4 to 382.2 ; the number of fruits per plant (C26) with a ratio of 8.76, and values ranging from 18.3 to 160.0 ; and the number of fruits per infructescence (C28) with a ratio of 7.64 and maximum and minimum values of 2.11 and 16.11 , respectively (Table 3 ). In contrast, the lowest relative ranges of variation included fruit apex angle (C33), with a ratio of 1.13 and values ranging from 118.8 to 134.7 degrees, fruit length/maximum width distance ratio (C36), with a ratio of 1.14 and maximum and minimum values of 2.20 and 2.50 , respectively, and seed width (C38) with a ratio of 1.21 and a range from 2.80 to $3.40 \mathrm{~mm}$. Regarding the coefficient of variation (CV), it ranged between $3.5 \%$ for fruit length/maximum width distance ratio (C36) and $87.0 \%$ for number of fruits per infructescence (C28). Descriptors with low CV values also included the fruit apex angle (C33; 3.9\%), seed length $(\mathrm{C} 37 ; 4.7 \%)$, and seed width $(\mathrm{C} 38 ; 4.9 \%)$, while descriptors with high values for $\mathrm{CV}$ included the number of fruits per plant $(\mathrm{C} 26 ; 68.7 \%)$, number of seeds per fruit (C39; 40.1\%), and fruit weight $(\mathrm{C} 34 ; 34.6 \%)$. None of the CV values for plant architecture, leaf, inflorescence and flower reached values $>20 \%$, while five infructescence, fruit and seed descriptors had CV values $>20 \%$ (Table 3). Broad-sense heritability values $\left(H^{2}\right)$ also presented a wide range of variation, with values between 0.03 for petal length (C21) and corolla diameter (C23), and 0.97 for number of fruits per 
infructescence (C28) (Table 3). In general, low or moderate $H^{2}$ values (always $<0.50$ ) were obtained for plant architecture, leaf, and inflorescence and flower descriptors. However, all infructescence, fruit and seed descriptors, except the fruit length/maximum width distance ratio $\left(\mathrm{C} 36 ; H^{2}=0.24\right)$ and infructescences per plant $\left(\mathrm{C} 27 ; H^{2}=0.46\right)$, had heritability values $>0.50$, and, notably, the number of fruits per plant (C26), number of fruits per infructescence (C28), fruit length (C29), fruit diameter (C32), fruit weight (C34), and number of seeds per fruit (C39), had heritability values $\geq 0.90$.

\section{Variation in the accessions studied}

ANOVA analyses revealed significant $(\mathrm{P}<0.05)$ differences among accessions for all descriptors used, except for three related to flower size: petal length $(\mathrm{C} 21)$, petal width (C22), and corolla diameter (C23) (Electronic Supplementary Material). Some of the most relevant differences found among accessions from the breeder's point of view are described below.

For plant architecture, the most relevant differences correspond to a difference of up to $47.1 \mathrm{~cm}$ in stem length $(\mathrm{C} 1 ; 116.3 \mathrm{~cm}$ in accession A36 vs. $163.4 \mathrm{~cm}$ in A29) and of $81.5 \mathrm{~cm}$ in crown diameter (C4; $77.5 \mathrm{~cm}$ in A40 and $159.0 \mathrm{~cm}$ in A20) (Table 3 and Electronic Supplementary Material). The number of fruits per plant (C26) varied considerably among accessions, with a mean of 40.5 fruits per plant. The lowest number of fruits per plant was found in accessions A27 (18.3), A21 (20.3), and A20 (20.5), while accessions with the highest number of fruits per plant were A41 (160.0), A34 (60.7), and A35 (55.6) (Electronic Supplementary Material). The number of fruits per infructescence (C28) ranged between 2.11 (A23) and 16.11 (A41) (Table 3 and Electronic Supplementary Material), although it is worth mentioning that the accession with the second-highest number of fruits per infructescence (A36) had many fewer 
fruits (4.29) than did A41. Regarding fruit length (C29) and width (C32), the lowest values were observed in accession A41 (3.98 cm for C29 and $3.74 \mathrm{~cm}$ for C32), while the highest ones occurred in A21 (7.92 cm for C29 and $5.97 \mathrm{~cm}$ for C32). Fruit weight (C34) had a mean value of $92.6 \mathrm{~g}$, with a wide variation among accessions, from $30.5 \mathrm{~g}$ for A41 to $154.2 \mathrm{~g}$ for A21; in this respect, five other accessions (A32, A33, A34, A35, and A36) had a mean fruit weight $<65 \mathrm{~g}$, and five others (A18, A20, A25, A26, and A27) had a mean fruit weight $>125 \mathrm{~g}$. Regarding the number of seeds per fruit (C39), accession A41 was characterized by a very low value, with only 3.4 seeds per fruit; when considering the remaining accessions, it varied between 124.5 for A34 and 382.2 for A21 (Table 3 and Electronic Supplementary Material).

\section{Differences among cultivar groups}

When considering the cultivar groups established, for most descriptors the value of the single accession of the red conical group did not overlap with the ranges of variation of any of the other groups, which indicates that this accession presents many morphological differences with respect to the rest of materials studied (Table 4 and Electronic Supplementary Material). In this respect, this single-accession group is characterized by a comparatively taller and thicker stem, shorter inflorescences and smaller flowers, and infructescences with a high number of small fruits, which have very few seeds. But when considering the remaining cultivar groups, the ranges of variation of accessions of the orange, orange pointed, purple, and red groups overlap for many descriptors (Table 4). The descriptors for which the ranges of variation of two or more of these cultivar groups do not overlap include internode length (C3), stem leaf central nerve length (C5), number of fruits per plant (C26), number of infructescences per plant (C27), number of fruits per infructescence (C28), fruit length (C29), fruit 
maximum width distance (C30) fruit width (C32), fruit apex angle (C33), fruit weight (C34), fruit length/width ratio (C35), fruit length/maximum width distance ratio (C36), and number of seeds per fruit (C39) (Table 4). In all cases, the ranges of variation of the orange and red cultivar groups do not overlap, with the orange group having greater internode length (C3), stem leaf central nerve length (C5), number of fruits per plant (C26), number of infructescences per plant (C27), number of fruits per infructescence (C28), and fruit apex angle (C33), and lower fruit length (C29), fruit maximum width distance (C30), fruit width (C32), fruit weight (C34), fruit length/width ratio (C35), fruit length/maximum width distance ratio (C36), and number of seeds per fruit (C39). Also, accessions of the orange pointed group have a smaller fruit apex angle (C33) than do the orange, red, or purple groups, and the red group also has a lower value than does the purple group for this descriptor (Table 4). Finally, the accessions of the purple cultivar group have lower values than do the red group for the fruit length/width ratio (C35).

\section{Correlations among descriptors}

Thirty-two out of 741 correlations between descriptors were significant $(r \geq 0.78)$ according to the Bonferroni significance test at $\mathrm{P} \leq 0.05$ (Table 5 and Electronic Supplementary Material). Most of these correlations (27) corresponded to descriptors from the same part of the plant, although, for the case of plant architecture, no significant correlations were found among these descriptors. We found four significant correlations between stem-leaf descriptors, and 11 between crown-leaf descriptors. All these significant correlations were positive and corresponded to leaf-size related descriptors as well as some size-related descriptors and the leaf apex angle (C10 for stem leaves and C16 for crown leaves). However, remarkably, no significant correlations were detected between any of the stem-leaf descriptors and crown-leaf 
descriptors (Table 5). For inflorescence and flower descriptors, only two significant positive correlations were found, namely, between inflorescence length $(\mathrm{C} 18)$ and inflorescence peduncle length (C19) and between petal length (C21) and corolla diameter (C23). For infructescence and fruit descriptors, we found nine significant correlations, of which seven were positive and two negative (Table 5). The positive correlations were those between fruits per plant (C26) and fruits per infructescence (C28), as well as six correlations involving four descriptors related to fruit size: fruit length (C29), fruit maximum width distance (C30), fruit diameter (C32) and fruit weight (C34); while the two negative ones were between number of fruits per plant (C26) and fruit length (C29) and between C26 and fruit maximum width distance (C30). For seed descriptors, the only significant correlation was found between seed length (C37) and width (C38). Finally, the five significant correlations involving descriptors from different groups involved negative correlations between stem leaf lobule length (C6) and fruit length/width ratio (C35) and between inflorescence length (C18) and number of fruits per infructescence (C28), and three positive correlations between number of seeds per fruit (C39) and three fruit-size descriptors, namely, fruit length (C29), diameter (C32) and weight (C34) (Table 5).

\section{Multivariate analyses}

The cophenetic correlation coefficient of the phenogram obtained from 39 descriptors has a value of 0.86 . The two basal branches (clusters 1 and 2 ) of the phenogram separate accession A41 from the rest of accessions (Figure 2). The latter accession presents the highest or lowest value from all accessions for 23 out of 39 descriptors studied, in particular for those related to infructescence, fruit and seeds (Table 4 and Electronic Supplementary Material). At the next level, two other branches (clusters 2.1 and 2.2) are 
distinguished; cluster 2.1 includes accessions A35, A36 and A37, which are characterized by low values for fruit-size descriptors, and cluster 2.2 the 20 remaining accessions. This latter cluster presents three subclusters (2.2.1, 2.2.2, and 2.2.3), of which 2.2.1 includes a single accession (A27), with the lowest number of fruits per plant (C26) and fewinfructescences per plant (C27), as well as few fruits per infructescence (C28); 2.2.2 includes eight accessions with high values for fruit-size descriptors; and 2.2.3 includes 11 accessions characterized by sharing intermediate values for fruit-size descriptors (Figure 2). With the exception of the red conical group, which contains the single accession A41, no clear-cut grouping of accessions from different cultivar groups can be observed in the phenogram. However, it is worth mentioning that cluster 2.1 does not contain any accessions of the orange or red groups, and that subcluster 2.2.3 does not contain any member of the red group, while most of the orange pointed accessions are included in it (Figure 2).

The first and second components of the PCA accounted for $25.33 \%$ and $22.08 \%$ of the total variation, respectively. The first component was positively correlated with fruit size (C29, C32, and C34), rounded fruit shape (C30 and C33), number of seeds per fruit (C39), crown leaf size (C12, C13, C14, and C15), as well as with other descriptors, like stem leaf apex angle (C10) and petal width (C22), and negatively correlated with descriptors related to number of fruits and of infructescences (C26, C27, and C28), elongated fruit shape (C35), as well as to others, like stem leaf central nerve length (C5), style length (C25) and crown diameter (C4) (Figure 3). The second component was positively correlated with the number of fruits (C26) and infructescences per plant (C28), stem diameter (C2), seed length (C37), fruit length/maximum width distance ratio $(\mathrm{C} 36$, which indicates a conical shape), crown leaf apex angle $(\mathrm{C} 16)$, as well as to some crown leaf size descriptors $(\mathrm{C} 12, \mathrm{C} 13, \mathrm{C} 14, \mathrm{C} 15$, and C17), and negatively 
correlated to inflorescence and flower size descriptors (C18, C19, C20, C21, C23, C24, and C25), and to fruit size descriptors (C29, C31, C32, and C34), elongated fruit shape (C30 and C35), as well as to the number of seeds per fruit (C39) (Figure 3). The projection of the accessions on a two-dimensional PCA plot (Figure 4) gives a distribution congruent with that obtained in the cluster analysis (Figure 2). In this respect, the second component clearly separated accession A41 (cluster 1 in the phenogram), with high positive values for this component, from the rest of accessions (cluster 2). On the other hand, the first component separated accessions A35, A36, and A37 (cluster 2.1), which have low values for this first component, from the remainding accessions (cluster 2.2) (Figure 4). Furthermore, within cluster 2.2, the accessions corresponding to subclusters 2.2.1, 2.2.2, and 2.2.3 are not intermingled, with accessions from subcluster 2.2.2 having higher values for the first component than those of subclusters 2.2.1 and 2.2.3. Regarding these latter subclusters, the single accession subcluster 2.2.1 is situated very close to subcluster 2.2.2, although it has a lower value for component 2 than do accessions of subcluster 2.2.3. As occurred with the cluster analysis, accessions of the different groups, with the exception of the red conical group accession A41, are intermingled in the PCA analysis, although all accessions of the orange and red groups plot in the same part of the graph, with high values for component 1 and low for component 2 (Figure 4).

\section{Discussion}

Tree tomato is a neglected Andean crop considered as one of the "Lost Crops of the Incas” (National Research Council 1989). Its genetic and phenotypic diversity and genetic resources have been barely studied, with no list of standard descriptors. To our 
knowledge, no reports exist on relationships among different cultivar groups or on the development of morphological descriptors for tree tomato characterization. In this respect, our work represents the first contribution to studying the diversity and relationships of cultivar groups of tree tomato, including a representation of the diversity of accessions, mostly from the Andean region, which is the center of origin of tree tomato (Bohs 1991; Bohs and Nelson 1997).

\section{Descriptors development}

Thirty-nine descriptors, focused on five groups of characters organized by plant part (plant architecture, leaf, inflorescence and flower, infructescence and fruit, and seed) have been used to describe morphological variation in this crop. The study of variation parameters for these descriptors has allowed us to identify those for which more variation exists in the germplasm, and which might potentially be more useful for the description and study of variation of tree tomato collections. In particular, heritability estimates are useful parameters for the management of genetic resources, as well as for selection and breeding programs (Nyquist 1991; Holland et al. 2003). When feasible, primary characterization descriptors should have high heritability values (Dudley and Moll 1969; Nyquist 1991), which allow greater selection efficiency (Wricke and Weber 1986; Dabholkar 1992). Here, we found that the highest values for heritability were for infructescence, fruit, and seed traits. These traits are of particular interest for primary characterization, given that these are also economically important parts of the plant for commercial production.

Variation for the traits studied 
We have found considerable diversity for most of the traits studied. For most of these traits, ranges of variation of five provisional cultivar groups (with the exception of the odd, red conical group) overlapped. The characters for which tree-tomato cultivar groups are typically distinguished, mostly fruit colour and shape, have been found to be controlled by a few major genes or QTLs in other solanaceous crops (Nunome et al. 2001; Zygier et al. 2005; Brewer et al. 2007). This may suggest that a similar situation occurs in tree tomato, as a monogenic or oligogenic control of these traits could facilitate their introgression into different genetic backgrounds and, thus, could explain the lack of morphological differentiation for most traits among cultivar groups.

Plant architecture traits are of interest for the establishment and management of crop plantations (Fischer 2000; Roos et al. 2005; Turnbull 2005). In this respect, we found important differences among accessions, although few differences among cultivar groups, except that the red conical group (accession A41) has a wider stem diameter than does any other cultivar group. Stem and crown leaves have shown important differences in size and shape. Stem leaves are present in juvenile plants and abscise as the plant develops, while crown leaves have a higher density in the crown and are measured when the plant has reached a more advanced developmental stage. Although important differences have been found among accessions for leaf traits, few differences have been observed among cultivar groups. Variation parameters for leaf traits have had low values, suggesting that these traits, which very likely have not been subjected to artificial selection, have undergone few changes during the domestication process (Zohary and Spiegel-Roy 1975).

Inflorescence and flower traits are critical for reproductive success and, although some variation was found for these traits, the scale was small. In the case of flower size, no differences were found among accessions, suggesting that the shape and size of 
flower organs are highly conserved in this species, a characteristic probably associated with insect-mediated pollination and possible indication that there has been selection pressure to maintain these traits during domestication (Pringle and Murray 1991b; Bernhardt 1996; Lewis and Considine 1999; Tcherkez 2004).

For most infructescence and fruit traits, important variation was found among accessions, and values for variation parameters were high, as might be expected for the organ/s for which a crop has been domesticated (Zohary and Spiegel-Roy 1975). For example, high diversity in fruit traits has been observed in other Solanum crops domesticated for their fruits, such as tomato, eggplant, and pepino (Anderson et al. 1996; Prohens et al. 2005; Ranc et al. 2008). This same phenomenon is also evident in other solanaceous crops domesticated for other parts of the plant. For example, potato tubers (Huamán and Spooner 2002) and tobacco leaves (Wernsman and Rufty 1987) display a wide diversity of sizes, shapes and colours.

Fruit size traits, which are of great commercial interest, were highly variable, with differences among accessions of $>5 \times$ in fruit weight. Also, important differences were found within the five cultivar groups. The red conical group had much smaller fruits than did the rest of cultivar groups, but this was compensated by a higher number of fruits per infructescence and plant and less seedy fruits. Some accessions, in particular A-21 and A-25 (purple group), A-20 (orange pointed), and A-18 (red), which have had the largest fruits (averages of 154, 132, 139 and $130 \mathrm{~g} /$ fruit, respectively) might be of interest for large-scale cultivation, as the commercial market demands large fruits (Jackson and Looney 1999; Prohens and Nuez 2000). The fact that there are largefruited accessions of various shapes in different cultivar groups may favour diversification in the marketing of tree tomato. It is also of interest to point out that the heaviest fruits obtained in our trial exceed those reported by other authors (El-Zeftawi et 
al. 1988; Pringle and Murray 1991a; Romero-Rodríguez et al. 1994; Prohens et al. 1996), suggesting that some of the accessions we evaluated may be of special interest for marketing.

The red conical group, represented by the single accession A-41, presented many differences, in particular for infructescence and fruit and seed traits with respect to the rest of cultivar groups. These differences are basically caused by a small fruit, a high number of fruits per plant and infructescence, a different fruit shape, and small number of seeds per fruit. Given its small size, it might be considered as a primitive or semidomesticated accession; however, the small number of seeds per fruit of this accession seems to rule out this hypothesis, as wild Solanum relatives have a high number of seeds per fruit (Bohs 2001). Accession A-41 might represent an intermediate step between normal non-parthenocarpic accessions and parthenocarpic accessions, which to our knowledge have not been described in cultivated tree tomato. In other Solanum crops, including tomato, pepper, eggplant, and pepino, types with few seeds or parthenocarpy, of high agronomic interest, have been described (Ikeda et al. 1999; Prohens et al. 1998; Gorguet et al. 2005). Alternatively, accession A-41 might be an aneuploid, polyploidy, or another cytologically abnormal type with reduced fertility (Pringle and Murray 1992a, 1992b).

Although traits related to seed size had relatively little variation and no differences were found among cultivar groups, some differences were observed among accessions. In this respect, although small seed size would be desirable for consumption, modifications in seed size may induce changes in viability, since small seeds usually have a lower germination percentage (Silvertown 1981), and this might partially explain the reduced variation for this trait. Also, a low number of seeds per fruit is desirable for consumption, and this occurs in other solanaceous crops, but a high 
number of seeds favours the formation of larger fruits, due to the influence of changes in plant growth regulators induced by the presence of seeds (Fos et al. 2000). This may result in a balancing of selective forces.

\section{Correlations among descriptors}

Most of the significant correlations among traits corresponded to those from the same plant part, mostly to traits measuring different characteristics of a single organ. For example, we found significant correlations among size-related traits of leaves and of fruits. This provides evidence of a shared genetic control or of the pleiotropic effect of one or a few genes that affect the organ size (Cooper et al. 2002; Sulmon et al. 2006). On the other hand, very few significant correlations were found among traits from different plant parts, suggesting that different genetic mechanisms control these developmental pathways. Comparative gene-expression studies among different organs in a number of species have shown that there are many differences among organs in the qualitative and quantitative gene expression (Schmid et al. 2005), which might explain these low correlation values. In fact, most of the correlations from the different plant parts corresponded to correlations between fruit and seed traits, which are known to be interrelated in many taxa.

\section{Multivariate analysis}

The cluster and PCA analysis results are congruent and clearly separate the morphologically distinct accession A-41 from other accessions. Accessions clustered mostly on the basis of fruit size and shape, as well as for the number of infructescences and fruits. Accessions from several cultivar groups (and countries) are scattered in the phenogram and PCA graph, and the resulting clusters or subclusters with two or more 
accessions include accessions from different cultivar groups. This indicates that, in some cases, there is more morphological similarity between accessions of different cultivar groups or countries than between accessions of the same cultivar group or country. This is probably caused by the fact that our initial classification of cultivar groups was made by considering only a few traits (fruit colour and shape), failing to account for other traits that significantly affect the plant morphology. The lack of grouping of accessions from different countries reflects a lack of regional differentiation, which is probably caused by the human-mediated transport and seed exchange from different countries, but also may be a function of small sample sizes for certain countries. Further research involving molecular studies may help in clarifying this issue.

\section{Acknowledgements}

This work was partially financed by the Ministerio de Ciencia e Innovación (RF200800008-00-00) and by the Secretaria Nacional de Ciencia y Tecnología from Ecuador (SENACYT). We are grateful to the curators of the genebanks that provided the germplasm needed to carry out this research.

\section{References}

Anderson GJ, Jansen RK, Kim Y (1996) The origin and relationships of the pepino, Solanum muricatum (Solanaceae): DNA restriction fragment evidence. Econ Bot 50:369-380. 
Bernhardt P (1996) Anther adaptation in animal pollination. In: D’Arcy WG, Keating RC (eds) The anther: form, function and phylogeny. Cambridge University Press, New York, USA. pp 192-220.

Bohs L (1989a) Ethnobotany of the genus Cyphomandra (Solanaceae). Econ Bot 43:143-163.

Bohs L (1989b) Solanum allophyllum (Miers) Standl. and the generic delimitation of Cyphomandra and Solanum (Solanaceae). Ann Missouri Bot Gard 76:11291140.

Bohs L (1991) Crossing studies in Cyphomandra (Solanaceae) and their systematic and evolutionary significance. Amer J Bot 78:1683-1693.

Bohs L (1994) Cyphomandra (Solanaceae). The New York Botanical Garden, Bronx, New York, USA.

Bohs L (1995) Transfer of Cyphomandra (Solanaceae) and its species to Solanum. Taxon 44:583-587.

Bohs L (2001) A revision of Solanum section Cyphomandropsis (Solanaceae). Syst Bot Monogr 61:1-85

Bohs L (2007) Phylogeny of the Cyphomandra clade of the genus Solanum (Solanaceae) based on ITS sequence data. Taxon 56:1012-1026.

Bohs L, Nelson A (1997) Solanum maternum (Solanaceae), a new Bolivian relative of the tree tomato. Novon 7:341-345.

Bohs L, Olmstead RG (1997) Phylogenetic relationships in Solanum (Solanaceae) based on $n d h F$ sequences. Syst Bot 22:5-17.

Boyes S, Strübi P (1997) Organic acid and sugar composition of three New Zeland grown tamarillo varieties (Solanum betaceum (Cav.)). New Zealand J Crop Hort Sci 25:79-83. 
Brewer MT, Moyseenko JB, Monforte AJ, van der Knaap E (2007) Morphological variation in tomato: A comprehensive study of quantitative trait loci controlling fruit shape and development. J Exp Bot 58:1339-1349.

Cooper M, Podlich DW, Micallef KP, Smith OS, Jensen NM, Chapman SC, Kruger NL (2002) Complexity, quantitative traits and plant breeding: A role for simulation modelling in the genetic improvement of crops. In: Kang MS (ed) Quantitative genetics, genomics and plant breeding. CABI Publishing, Oxon, UK, pp 143166.

Dabholkar AR (1992) Elements of biometrical genetics. Concept Publishing Co., New Delhi, India.

Day Rubenstein K, Smale M, Widrlechner MP (2006) Demand for genetic resources and the U.S. National Plant Germplasm System. Crop Sci 46:1021-1031.

de Vicente MC, Guzmán FA, Engels J, Rao VR (2006) Genetic characterization and its use in decision making for the conservation of crop germplasm. In: Ruane J, Sonnino A (eds) The role of biotechnology in exploring and protecting agricultural genetic resources. Food and Agriculture Organization, Rome, Italy, pp 121-128.

Dudley JW, Moll RH (1969) Interpretation and use of estimates of heritability and genetic variances in plant breeding. Crop Sci 9:257-262.

El-Zeftawi BM, Brohier L, Dooley L, Goubran FH, Holmes R, Scott B (1988) Some maturity indices for tamarillo and pepino fruits. J Hort Sci 63:163-169.

Enciso-Rodríguez F, Martínez R, Lobo M, Barrero LS (2010) Genetic variation in the Solanaceae fruit bearing species lulo and tree tomato revealed by Conserved Ortholog (COSII) markers. Genet Molec Biol 33:271-278. 
Fischer G (2000) Ecophysiological aspects of fruit growing in tropical highlands. Acta Hort 531:91-98.

Fos M, Nuez F, García-Martínez JL (2000) The gene pat-2, which induces natural parthenocarpy, alters the giberellin content in unpollinated tomato ovaries. Plant Physiol 122:471-479.

Gorguet B, van Heusden AW, Lindhout P (2005) Parthenocarpic fruit development in tomato. Plant Biol 7:131-139.

Hammer K, Arrowsmith N, Gladis T (2003) Agrobiodiversity with emphasis on plant genetic resources. Naturwissenschaften 90:241-250.

Hernández-Bermejo JE, León J (1992) Cultivos marginados: Otra perspectiva de 1492. Food and Agriculture Organization, Rome, Italy.

Hochberg Y (1988) A sharper Bonferroni procedure for multiple tests of significance. Biometrika 75:800-803.

Holdridge LR (1967) Life zone ecology. Tropical Science Center, San José, Costa Rica. Holland JB, Nyquist WE, Cervantes-Martínez CT (2003) Estimating and interpreting heritability for plant breeding: An update. Plant Breed Rev 22:9-111.

Huamán Z, Spooner DM (2002) Reclassification of landrace populations of cultivated potatoes (Solanum sect. Petota). Amer J Bot 89:947-965.

IBPGR (1990) Descriptors for eggplant. International Board for Plant Genetic Resources, Rome, Italy.

Ikeda T, Yakushiji H, Oda M, Taji A, Imada S (1999) Growth dependence of ovaries of facultatively parthenocarpic eggplant in vitro on indole-3-acetic acid content. Sci. Hort. 79:143-150.

IPGRI (1996) Descriptors for tomato (Lycopersicom spp.). International Plant Genetic Resources Institute, Rome, Italy. 
IPGRI (2004) Descriptors for pepino (Solanum muricatum). International Plant Genetic Resources Institute, Rome, Italy.

Jackson D, Looney N (1999) Producing and marketing quality fruit. In: Jackson D, Looney N (eds) Temperate and subtropical fruit production, CABI, Oxon, UK, pp 85-108.

Kwon YS, Park SG, Yi SI (2009) Assessment of genetic variation among commercial tomato (Solanum lycopersicum L.) varieties using SSR markers and morphological characteristics. Genes Genom 31:1-10.

Lewis DH, Considine JA (1999) Pollination and fruit set in the tamarillo (Cyphomandra betacea (Cav.) Sendt.) 1. Floral biology. New Zealand J Crop Hort Sci 27:101112.

Lester RN, Hawkes JG (2001) Solanaceae. In: Hanelt P and Institute of Plant Genetics and Crop Reesearch (eds) Mansfeld's encyclopedia of agricultural and horticultural crops (except ornamentals), vol 4. Springer, Berlin, Germany, pp $1790-1856$.

Mantel N (1967) The detection of disease clustering and generalized regression approach. Cancer Res 27:209-220.

Mertz C, Gancel AL, Gunata Z, Alter P, Dhuique-Mayer C, Vaillant F, Pérez AM, Ruales J, Brat P (2009) Phenolic compounds, carotenoids and antioxidant activity of three tropical fruits. J Food Comp Anal 22:381-387.

Mohammadi SA, Prassana BM (2003) Analysis of genetic diversity in crop plants salient statistical tools and considerations. Crop Sci 43:1235-1248.

Muñoz-Falcón J, Prohens J, Vilanova S, Nuez F (2008) Characterization, diversity, and relationships of the Spanish striped (Listada) eggplants: A model for the enhancement and protection of local heirlooms. Euphytica 164:405-419. 
Mwithiga G; Mukolwe MI, Shitanda D, Karanja PN (2007) Evaluation of the effect of ripening on the sensory quality and properties of tamarillo (Cyphomandra betaceae) fruits. J Food Eng 79:117-123.

National Research Council (1989) Lost crops of the Incas: Little-known plants of the Andes with promise for worldwide cultivation. National Academy Press, Washington, DC, USA.

Nunome T, Ishiguro K, Yoshida T, Hirai M (2001) Mapping of fruit shape and color development traits in eggplant (Solanum melongena L.) based on RAPD and AFLP markers. Breed Sci 51:19-26.

Nyquist WE (1991) Estimation of heritability and prediction of selection response in plant populations. Crit Rev Plant Sci 10:235-322.

Pileri AM (1989) Il tamarillo. Rivista di Frutticultura 51(11):67-70.

Pringle GJ, Murray BG (1991a) Interspecific hybridisation involving the tamarillo, Cyphomandra betacea (Cav.) Sendt. (Solanaceae). New Zealand J Crop Hort Sci 19:103-111.

Pringle GJ, Murray BG (1991b) Reproductive biology of the tamarillo, Cyphomandra betacea (Cav.) Sendt. (Solanaceae), and some wild relatives. New Zealand J Crop Hort Sci 19:263-273.

Pringle GJ, Murray BG (1992a) Polyploidy and aneuploidy in the tamarillo, Cyphomandra betacea (Cav.) Sendt. (Solanaceae) I. Spontaneous polyploidy and features of the euploids. Plant Breed 108:132-138.

Pringle GJ, Murray BG (1992b) Polyploidy and aneuploidy in the tamarillo, Cyphomandra betacea (Cav.) Sendt. (Solanaceae) II. Induction of tetraploidy, interploidy crosses and aneuploidy. Plant Breed 108:139-148. 
Prohens J, Blanca J, Nuez F (2005) Morphological and molecular variation in a collection of eggplants from a secondary center of diversity: Implications for conservation and breeding. J Amer Soc Hort Sci 130:54-63.

Prohens J, Nuez F (2000) The tamarillo (Cyphomandra betacea): A review of a promising small crop. Small Fruits Rev 1(2):43-68.

Prohens J, Rodríguez-Burruezo A, Nuez F (2004) Breeding Andean Solanaceae fruit crops for adaptation to subtropical climates. Acta Hort 662:129-137.

Prohens J, Ruiz JJ, Nuez F (1996) Advancing the tamarillo harvest by induced postharvest ripening. Hortscience 31:109-111.

Prohens J, Ruiz JJ, Nuez F (1998) The inheritance of parthenocarpy and associated traits in pepino. J Amer Soc Hort Sci 123:376-380.

Ranc L, Muños S, Santoni S, Causse M (2008) A clarified position for Solanum lycopersicum var. cerasiforme in the evolutionary history of tomatoes (Solanaceae). BMC Plant Biol 8:130.

Rodríguez-Burruezo A, Prohens J, Nuez F (2002) Genetic analysis of quantitative traits in pepino (Solanum muricatum) in two growing seasons. J Amer Soc Hort Sci 127:271-278.

Romero-Rodríguez MA, Vázquez-Oderiz ML, López-Hernández J, Simal-Lozano J (1994) Composition of babaco, feijoa, pasion-fruit and tamarillo produced in Galicia (NW Spain). Food Chem 49:251-255.

Roos JJ, Reid JB, Weller JL, Symons GM (2005) Shoot architecture I: Regulation of stem length. In: Turnbull CGN (ed) Plant architecture and its manipulation. Blackwell Publishing, Oxford, UK, pp 57-91. 
Schmid M, Davison TS, Henz SR, Pape UJ, Demar M, Vingron M, Schölkopf B, Weigel D, Lohmann JU (2005) A gene expression map of Arabidopsis thaliana development. Nat Genet 37:501-506.

Silvertown JW (1981) Seed size, life span and germination date as coadadpted features of plant life history. Amer Natural 118:860-864.

Sneath PHA, Sokal RR (1973) Numerical taxonomy. WH Freeman, San Francisco, USA

Spooner DM, Hetterscheid WLA, van den Berg RG, Brandenburg WA (2003) Plant nomenclature and taxonomy - an horticultural and agronomic perspective. Hort Rev 28:1-60.

Sulmon C, Gouesbet G, Couee I, Cabello-Hurtado F, Cavalier A, Penno C, Zaka R, Bechtold N, Thomas D, El Amrani (2006) The pleiotropic Arabidopsis frd mutation with altered coordination of chloroplast biogenesis, cell size and differentiation, organ size and number. Gene 382:88-99.

Tcherkez G (2004) Flowers: Evolution of the floral architecture of angiosperms. Science Publishers, Enfield, NH, USA.

Turnbull CGN (2005) Shoot architecture II: Control of branching. In: Turnbull CGN (ed) Plant architecture and its manipulation. Blackwell Publishing, Oxford, UK, pp 92-120.

Vasco C, Avila J, Ruales J, Svanberg U, Kamal-Eldin A (2009) Physical and chemical characteristics of golden-yellow and purple-red varieties of tamarillo fruit (Solanum betaceum Cav.). Int J Food Sci Nutr 60:278-288.

Weese TL, Bohs L (2007) A three-gene phylogeny of the genus Solanum (Solanaceae). Syst Bot 32:445-463. 
Wernsman EA, Rufty RC (1987) Tobacco. In: Fehr W (ed.). Principles of cultivar development, vol. 2. Macmillan Publ., New York, USA, pp 669-698.

Wricke G, Weber WE (1986) Quantitative genetics and selection in plant breeding. Walter de Gruyter, Berlin.

Zohary D, Spiegel-Roy P (1975) Beginning of fruit growing in the Old World. Science $187: 319-327$.

Zygier S, Chaim AB, Efrati A, Kaluzky G, Borvsky Y, Paran I (2005) QTLs mapping for fruit size and shape in chromosomes 2 and 4 in pepper and a comparison of the pepper QTL map with that of tomato. Theor Appl Genet 111:437-445. 
Table 1. Tree tomato accessions, cultivar groups, and origins, including province or department and country.

\begin{tabular}{|c|c|c|c|c|}
\hline & Germplasm & Accession code & & \\
\hline Accession & bank & in germplasm bank & Cultivar Group & Origin \\
\hline$\overline{A-16}$ & UPV & ECU-1134 & Orange & Morona Santiago (Ecuador) \\
\hline A-17 & UPV & ECU-1221 & Orange pointed & Azuay (Ecuador) \\
\hline A-18 & UPV & ECU-1248 & Red & Tungurahua (Ecuador) \\
\hline A-19 & UPV & ECU-1295 & Orange pointed & Carchi (Ecuador) \\
\hline A-20 & UPV & ECU-1567 & Orange pointed & El Oro (Ecuador) \\
\hline A-21 & UTPL & ECUt-001 & Purple & Loja (Ecuador) \\
\hline A-22 & UTPL & ECUt-002 & Orange & Azuay (Ecuador) \\
\hline A-23 & UTPL & ECUt-003 & Orange pointed & Azuay (Ecuador) \\
\hline A-24 & UTPL & ECUt-004 & Red & Azuay (Ecuador) \\
\hline A-25 & UTPL & ECUt-005 & Purple & Azuay (Ecuador) \\
\hline A-26 & UTPL & ECUt-006 & Red & Tungurahua (Ecuador) \\
\hline A-27 & UTPL & ECUt-007 & Red & Tungurahua (Ecuador) \\
\hline A-29 & UTPL & ECUt-008 & Orange & Cotopaxi (Ecuador) \\
\hline A-30 & UPV & QB-54 & Purple & Boyacá (Colombia) \\
\hline A-31 & UPV & UNT-08 & Orange pointed & Lima (Peru) \\
\hline A-32 & UPV & PT-087 & Orange pointed & Chachapoyas (Peru) \\
\hline A-33 & UPV & PT-221 & Orange pointed & Cajamarca (Peru) \\
\hline A-34 & UPV & РT242 & Orange pointed & Cajamarca (Peru) \\
\hline A-35 & UPV & BOL-14 & Orange pointed & Cochabamba (Bolivia) \\
\hline A-36 & UPV & BOL-116 & Orange pointed & Santa Cruz (Bolivia) \\
\hline A-37 & UPV & EUR-CY-1 & Purple & Lisboa (Portugal) \\
\hline A-39 & UPV & NZ-1 & Purple & New Zealand \\
\hline A- -40 & UPV & NZ-2 & Purple & New Zealand \\
\hline A-41 & UTPL & ECUt-009 & Red conical & Saraguro (Ecuador) \\
\hline
\end{tabular}


Table 2. Quantitative descriptors developed for tree tomato organized by plant part, with measurement protocols.

\begin{tabular}{|c|c|c|}
\hline Descriptor & $\begin{array}{l}\text { Descriptor } \\
\text { code }\end{array}$ & Instructions for measurement \\
\hline \multicolumn{3}{|c|}{ Plant architecture } \\
\hline Stem length $(\mathrm{cm})$ & $\mathrm{C} 1$ & $\begin{array}{l}\text { Distance from the stem base to the branching point in } \\
\text { non-decapitated plants }\end{array}$ \\
\hline Stem diameter $(\mathrm{cm})$ & $\mathrm{C} 2$ & $\begin{array}{l}\text { Stem diameter at } 30 \mathrm{~cm} \text { below the branching point in } \\
\text { non-decapitated plants }\end{array}$ \\
\hline Internode length $(\mathrm{cm})$ & $\mathrm{C} 3$ & Distance between the first and second nodes of the stem \\
\hline Crown diameter $(\mathrm{cm})$ & $\mathrm{C} 4$ & $\begin{array}{l}\text { Measurement of the diameter of the horizontal } \\
\text { projection on the ground of the crown } \\
\text { Leaf }\end{array}$ \\
\hline $\begin{array}{l}\text { Stem leaf central nerve length } \\
(\mathrm{cm})\end{array}$ & $\mathrm{C} 5$ & $\begin{array}{l}\text { Length of the central nerve of the lamina from the } \\
\text { petiole insertion to the apex in stem leaves }\end{array}$ \\
\hline Stem leaf lobules length (cm) & C6 & $\begin{array}{l}\text { Difference between the lamina length and the leaf } \\
\text { central nerve length in stem leaves }\end{array}$ \\
\hline $\begin{array}{l}\text { Stem leaf width at the petiole } \\
\text { insertion }(\mathrm{cm})\end{array}$ & $\mathrm{C} 7$ & $\begin{array}{l}\text { Width of the leaf lamina at the petiole insertion point in } \\
\text { stem leaves }\end{array}$ \\
\hline Stem leaf maximum width $(\mathrm{cm})$ & $\mathrm{C} 8$ & Maximum width of the leaf lamina in stem leaves \\
\hline $\begin{array}{l}\text { Stem leaf distance of the } \\
\text { maximum width point }(\mathrm{cm})\end{array}$ & C9 & $\begin{array}{l}\text { Distance between the proximal part of the leaf lamina } \\
\text { and the maximum width point in stem leaves }\end{array}$ \\
\hline Stem leaf apex angle (degrees) & $\mathrm{C} 10$ & $\begin{array}{l}\text { Angle formed by the leaf lamina edges at } 5 \mathrm{~cm} \text { of the } \\
\text { apex in stem leaves }\end{array}$ \\
\hline $\begin{array}{l}\text { Crown leaf central nerve length } \\
(\mathrm{cm})\end{array}$ & $\mathrm{C} 11$ & $\begin{array}{l}\text { Length of the central nerve of the lamina from the } \\
\text { petiole insertion to the apex in crown leaves }\end{array}$ \\
\hline Crown leaf lobules length $(\mathrm{cm})$ & $\mathrm{C} 12$ & $\begin{array}{l}\text { Difference between the lamina length and the leaf } \\
\text { central nerve length in crown leaves }\end{array}$ \\
\hline $\begin{array}{l}\text { Crown leaf width at the petiole } \\
\text { insertion }(\mathrm{cm})\end{array}$ & $\mathrm{C} 13$ & $\begin{array}{l}\text { Width of the leaf lamina at the petiole insertion point in } \\
\text { crown leaves }\end{array}$ \\
\hline Crown leaf maximum width $(\mathrm{cm})$ & $\mathrm{C} 14$ & Maximum width of the leaf lamina in crown leaves \\
\hline $\begin{array}{l}\text { Crown leaf distance of the } \\
\text { maximum width point }(\mathrm{cm})\end{array}$ & $\mathrm{C} 15$ & $\begin{array}{l}\text { Distance between the proximal part of the leaf lamina } \\
\text { and the maximum width point in crown leaves }\end{array}$ \\
\hline Crown leaf apex angle (degrees) & $\mathrm{C} 16$ & $\begin{array}{l}\text { Angle formed by the leaf lamina edges at } 5 \mathrm{~cm} \text { of the } \\
\text { apex in crown leaves }\end{array}$ \\
\hline Crown leaf petiole length $(\mathrm{cm})$ & $\mathrm{C} 17$ & Length of the leaf petiole in crown leaves \\
\hline & Inflore & cence and flower \\
\hline Inflorescence length $(\mathrm{cm})$ & $\mathrm{C} 18$ & Distance between distal part of the inflorescence \\
\hline
\end{tabular}


Inflorescence peduncle length

(cm)

Inflorescence rachis Internode

length $(\mathrm{cm})$

Petal length $(\mathrm{cm})$

Petal width $(\mathrm{cm})$

Corolla diameter $(\mathrm{cm})$

Anther length (cm)

Style length $(\mathrm{cm})$

Fruits per plant

Infructescences per plant

Fruits per infructescence

Fruit length $(\mathrm{cm})$

Fruit maximum width distance

(cm)

Fruit pedicel length $(\mathrm{cm})$

Fruit width $(\mathrm{cm})$

Fruit apex angle (degrees)

Fruit weight (g)

Fruit length/width ratio

Fruit length/maximum width

distance ratio

Seed length (mm)

Seed width $(\mathrm{mm})$

Seeds per fruit peduncle and the distal part of the inflorescence

C19 Length of the inflorescence peduncle

C20 Distance between the first and second nodes of the inflorescence rachis

C21 Length of the petal

C22 Maximum width of the petal

C23 Diameter of the corolla

C24 Length of the anther

C25 Length of the style

Infructescence and fruit

C26 Number of fruits in adult plants of the same age

C27 Number of infructescences in adult plants of the same age

C28 Average number of fruits per infructescence in a plant

C29 Length of the berry from the proximal to the distal part

C30 Distance between the proximal part of the berry and the maximum width point

C31 Length of the fruit pedicel

C32 Maximum width of the berry

C33 Angle formed by the berry edges at $2 \mathrm{~cm}$ of the apex

C34 Weight of the fruit

C35 Ratio between fruit length (C29) and fruit diameter (C32)

C36 Ratio between fruit length (C29) and fruit maximum width distance (C30).

Seed

C37 Seed length

C38 Seed width

C39 Average number of seeds per fruit 
Table 3. Mean, minimum, and maximum and minimum values, range, maximum value/minimum value ratio, standard deviation $(\mathrm{SD})$, coefficient of variation $(\mathrm{CV})$ and broad sense heritability $\left(H^{2}\right)$ for the 39 descriptors in the 24 tree tomato accessions studied.

\begin{tabular}{|c|c|c|c|c|c|c|c|c|c|}
\hline Descriptor & $\begin{array}{l}\text { Descriptor } \\
\text { code }\end{array}$ & Mean & Minimum & Maximum & Range & $\begin{array}{l}\text { Maximum/ } \\
\text { Minimum }\end{array}$ & SD & $\begin{array}{l}\mathrm{CV} \\
(\%)\end{array}$ & $H^{2}$ \\
\hline \multicolumn{10}{|c|}{ Plant architecture } \\
\hline Stem length $(\mathrm{cm})$ & $\mathrm{C} 1$ & 137.0 & 116.3 & 163.4 & 47.1 & 1.41 & 11.4 & 8.3 & 0.35 \\
\hline Stem diameter $(\mathrm{cm})$ & $\mathrm{C} 2$ & 3.44 & 2.60 & 4.70 & 2.10 & 1.81 & 0.42 & 12.6 & 0.30 \\
\hline Internode length (cm) & $\mathrm{C} 3$ & 4.24 & 3.57 & 5.74 & 2.17 & 1.61 & 0.44 & 10.4 & 0.14 \\
\hline Crown diameter $(\mathrm{cm})$ & $\mathrm{C} 4$ & 125.5 & 77.5 & 159.0 & 81.5 & 2.05 & 21.2 & 16.9 & 0.24 \\
\hline \multicolumn{10}{|c|}{ Leaf } \\
\hline $\begin{array}{l}\text { Stem leaf central nerve length } \\
(\mathrm{cm})\end{array}$ & $\mathrm{C} 5$ & 29.6 & 22.4 & 34.3 & 11.9 & 1.53 & 2.4 & 8.0 & 0.22 \\
\hline Stem leaf lobules length $(\mathrm{cm})$ & C6 & 5.84 & 3.73 & 6.95 & 3.22 & 1.86 & 0.76 & 13.0 & 0.27 \\
\hline $\begin{array}{l}\text { Stem leaf width at the petiole } \\
\text { insertion }(\mathrm{cm})\end{array}$ & $\mathrm{C} 7$ & 22.7 & 18.0 & 25.3 & 7.3 & 1.40 & 1.9 & 8.4 & 0.21 \\
\hline Stem leaf maximum width $(\mathrm{cm})$ & $\mathrm{C} 8$ & 25.0 & 20.8 & 27.7 & 6.9 & 1.33 & 1.7 & 7.0 & 0.15 \\
\hline $\begin{array}{l}\text { Stem leaf distance of the } \\
\text { maximum width point }(\mathrm{cm})\end{array}$ & $\mathrm{C} 9$ & 11.2 & 9.55 & 12.5 & 2.9 & 1.31 & 0.7 & 6.4 & 0.04 \\
\hline Stem leaf apex angle (degrees) & $\mathrm{C} 10$ & 76.9 & 65.3 & 81.7 & 16.4 & 1.25 & 4.1 & 5.3 & 0.44 \\
\hline $\begin{array}{l}\text { Crown leaf central nerve length } \\
(\mathrm{cm})\end{array}$ & $\mathrm{C} 11$ & 21.8 & 15.5 & 25.3 & 9.8 & 1.63 & 2.2 & 10.2 & 0.39 \\
\hline Crown leaf lobules length $(\mathrm{cm})$ & $\mathrm{C} 12$ & 4.29 & 2.66 & 5.84 & 3.18 & 2.20 & 0.80 & 18.6 & 0.43 \\
\hline $\begin{array}{l}\text { Crown leaf width at the petiole } \\
\text { insertion }(\mathrm{cm})\end{array}$ & $\mathrm{C} 13$ & 15.3 & 9.54 & 19.0 & 9.5 & 1.99 & 2.3 & 15.0 & 0.47 \\
\hline $\begin{array}{l}\text { Crown leaf maximum width } \\
(\mathrm{cm})\end{array}$ & $\mathrm{C} 14$ & 17.5 & 11.0 & 20.9 & 9.9 & 1.90 & 2.3 & 13.4 & 0.47 \\
\hline $\begin{array}{l}\text { Crown leaf distance of the } \\
\text { maximum width point }(\mathrm{cm})\end{array}$ & $\mathrm{C} 15$ & 7.54 & 5.04 & 8.80 & 3.76 & 1.75 & 0.95 & 12.7 & 0.28 \\
\hline Crown leaf apex angle (degrees) & $\mathrm{C} 16$ & 66.8 & 41.0 & 83.8 & 42.9 & 2.05 & 11.1 & 16.5 & 0.40 \\
\hline Crown leaf petiole length $(\mathrm{cm})$ & $\mathrm{C} 17$ & 8.17 & 6.02 & 9.88 & 3.86 & 1.64 & 0.9 & 11.1 & 0.28 \\
\hline \multicolumn{10}{|c|}{ Inflorescence and flower } \\
\hline Inflorescence length (cm) & $\mathrm{C} 18$ & 8.05 & 4.73 & 9.56 & 4.83 & 2.02 & 0.89 & 11.1 & 0.49 \\
\hline $\begin{array}{l}\text { Inflorescence peduncle length } \\
(\mathrm{cm})\end{array}$ & C19 & 3.54 & 1.63 & 4.93 & 3.30 & 3.02 & 0.62 & 17.5 & 0.36 \\
\hline $\begin{array}{l}\text { Inflorescence rachis internode } \\
\text { length }(\mathrm{cm})\end{array}$ & $\mathrm{C} 20$ & 2.23 & 1.61 & 2.77 & 1.16 & 1.72 & 0.23 & 10.1 & 0.36 \\
\hline Petal length (cm) & $\mathrm{C} 21$ & 1.19 & 1.00 & 1.32 & 0.32 & 1.32 & 0.08 & 6.7 & 0.03 \\
\hline Petal width (cm) & $\mathrm{C} 22$ & 0.48 & 0.42 & 0.56 & 0.14 & 1.33 & 0.04 & 7.6 & 0.17 \\
\hline
\end{tabular}




\begin{tabular}{|c|c|c|c|c|c|c|c|c|c|}
\hline Corolla diameter $(\mathrm{cm})$ & $\mathrm{C} 23$ & 2.39 & 2.00 & 2.64 & 0.64 & 1.32 & 0.17 & 7.0 & 0.03 \\
\hline Anther length (cm) & $\mathrm{C} 24$ & 0.57 & 0.48 & 0.66 & 0.18 & 1.38 & 0.04 & 6.6 & 0.24 \\
\hline Style length (cm) & $\mathrm{C} 25$ & 0.59 & 0.48 & 0.69 & 0.21 & 1.44 & 0.04 & 6.8 & 0.33 \\
\hline \multicolumn{10}{|c|}{ Infructescence and fruit } \\
\hline Fruits per plant & $\mathrm{C} 26$ & 40.5 & 18.3 & 160.0 & 141.7 & 8.76 & 27.8 & 68.7 & 0.92 \\
\hline Infructescences per plant & $\mathrm{C} 27$ & 13.5 & 7.20 & 22.1 & 14.9 & 3.07 & 3.6 & 26.6 & 0.46 \\
\hline Fruits per infructescence & $\mathrm{C} 28$ & 3.22 & 2.11 & 16.11 & 14.00 & 7.64 & 2.80 & 87.0 & 0.97 \\
\hline Fruit length $(\mathrm{cm})$ & $\mathrm{C} 29$ & 6.47 & 3.98 & 7.92 & 3.94 & 1.99 & 0.87 & 13.5 & 0.96 \\
\hline $\begin{array}{l}\text { Fruit maximum width distance } \\
(\mathrm{cm})\end{array}$ & $\mathrm{C} 30$ & 2.76 & 1.60 & 3.25 & 1.65 & 2.03 & 0.35 & 12.8 & 0.86 \\
\hline Fruit pedicel length $(\mathrm{cm})$ & $\mathrm{C} 31$ & 4.77 & 3.91 & 5.91 & 2.00 & 1.51 & 0.43 & 8.9 & 0.55 \\
\hline Fruit width $(\mathrm{cm})$ & $\mathrm{C} 32$ & 4.95 & 3.74 & 5.97 & 2.23 & 1.60 & 0.63 & 12.7 & 0.96 \\
\hline Fruit apex angle (degrees) & $\mathrm{C} 33$ & 127.8 & 118.8 & 134.7 & 15.9 & 1.13 & 5.0 & 3.9 & 0.76 \\
\hline Fruit weight (g) & $\mathrm{C} 34$ & 92.6 & 30.51 & 154.2 & 123.7 & 5.05 & 32.0 & 34.6 & 0.96 \\
\hline Fruit length/width ratio & $\mathrm{C} 35$ & 1.31 & 1.06 & 1.49 & 0.43 & 1.41 & 0.11 & 8.0 & 0.86 \\
\hline Fruit length/maximum width & $\mathrm{C} 36$ & 2.35 & 2.20 & 2.50 & 0.30 & 1.14 & 0.08 & 3.5 & 0.24 \\
\hline & & & Seed & & & & & & \\
\hline Seed length (mm) & $\mathrm{C} 37$ & 3.83 & 3.40 & 4.20 & 0.80 & 1.24 & 0.18 & 4.7 & 0.67 \\
\hline Seed width (mm) & C38 & 3.13 & 2.80 & 3.40 & 0.60 & 1.21 & 0.15 & 4.9 & 0.72 \\
\hline Seeds per fruit & C39 & 249.4 & 3.4 & 382.2 & 378.8 & 112.40 & 100.0 & 40.1 & 0.90 \\
\hline
\end{tabular}


Table 4. Mean, minimum (Min), and maximum (Max) values for each of the cultivar groups. Numbers in brackets indicate the number of accessions in each cultivar group.

\begin{tabular}{|c|c|c|c|c|c|c|c|c|c|c|c|c|c|c|}
\hline \multirow{2}{*}{ Descriptors } & \multirow{2}{*}{$\begin{array}{l}\text { Descriptor } \\
\text { code }\end{array}$} & \multicolumn{3}{|c|}{ Orange $(n=3)$} & \multicolumn{3}{|c|}{ Orange pointed $(\mathrm{n}=10)$} & \multicolumn{3}{|c|}{ Purple (n=6) } & \multicolumn{3}{|c|}{$\operatorname{Red}(n=4)$} & \multirow{2}{*}{$\begin{array}{c}\text { Red } \\
\text { conical } \\
(\mathrm{n}=1) \\
\text { Mean }\end{array}$} \\
\hline & & Mean & Min & Max & Mean & Min & $\operatorname{Max}$ & Mean & Min & Max & Mean & Min & Max & \\
\hline \multicolumn{15}{|c|}{ Plant architecture } \\
\hline Stem length (cm) & $\mathrm{C} 1$ & 141.3 & 127.7 & 163.4 & 133.0 & 116.3 & 147.8 & 140.1 & 129.5 & 160.1 & 137.1 & 129.6 & 143.5 & 145.9 \\
\hline Stem diameter $(\mathrm{cm})$ & $\mathrm{C} 2$ & 3.49 & 3.29 & 3.59 & 3.49 & 3.01 & 4.06 & 3.31 & 2.60 & 3.71 & 3.15 & 2.86 & 3.52 & 4.70 \\
\hline Internode length $(\mathrm{cm})$ & $\mathrm{C} 3$ & 4.54 & 4.46 & 4.63 & 4.22 & 3.57 & 5.74 & 4.32 & 4.01 & 4.51 & 3.95 & 3.70 & 4.17 & 4.25 \\
\hline Crown diameter (cm) & $\mathrm{C} 4$ & 111.2 & 98.6 & 132.7 & 136.3 & 112.0 & 159.0 & 112.0 & 77.5 & 142.0 & 124.6 & 116.0 & 147.9 & 144.3 \\
\hline \multicolumn{15}{|c|}{ Leaf } \\
\hline Stem leaf central nerve length $(\mathrm{cm})$ & $\mathrm{C} 5$ & 30.0 & 29.1 & 31.8 & 30.7 & 28.1 & 34.3 & 29.1 & 22.4 & 31.9 & 27.6 & 26.2 & 28.8 & 29.3 \\
\hline Stem leaf lobules length $(\mathrm{cm})$ & C6 & 6.15 & 5.21 & 6.78 & 5.39 & 3.73 & 6.34 & 6.32 & 5.76 & 6.61 & 5.75 & 5.36 & 6.34 & 6.95 \\
\hline $\begin{array}{l}\text { Stem leaf width at the petiole insertion } \\
(\mathrm{cm})\end{array}$ & $\mathrm{C} 7$ & 23.9 & 21.9 & 25.2 & 22.1 & 18.0 & 24.7 & 23.3 & 20.5 & 25.3 & 22.4 & 21.2 & 23.1 & 23.7 \\
\hline Stem leaf maximum width $(\mathrm{cm})$ & $\mathrm{C} 8$ & 26.0 & 24.4 & 27.4 & 24.9 & 20.8 & 27.7 & 25.2 & 21.8 & 27.2 & 24.5 & 23.2 & 25.2 & 24.3 \\
\hline $\begin{array}{l}\text { Stem leaf distance of the maximum } \\
\text { width point }(\mathrm{cm})\end{array}$ & $\mathrm{C} 9$ & 11.8 & 10.8 & 12.3 & 11.3 & 9.6 & 12.4 & 11.1 & 10.2 & 12.5 & 11.0 & 10.2 & 11.4 & 11.0 \\
\hline Stem leaf apex angle (degrees) & $\mathrm{C} 10$ & 78.7 & 77.1 & 81.7 & 74.9 & 65.3 & 81.6 & 77.7 & 73.4 & 80.7 & 78.6 & 76.7 & 80.1 & 79.8 \\
\hline Crown leaf central nerve length $(\mathrm{cm})$ & $\mathrm{C} 11$ & 22.2 & 21.3 & 23.0 & 22.3 & 20.1 & 23.6 & 20.6 & 15.5 & 23.3 & 22.4 & 17.0 & 25.3 & 21.2 \\
\hline Crown leaf lobules length $(\mathrm{cm})$ & $\mathrm{C} 12$ & 4.42 & 3.78 & 5.41 & 3.99 & 2.98 & 4.95 & 4.21 & 2.66 & 4.89 & 4.67 & 3.50 & 5.44 & 5.84 \\
\hline $\begin{array}{l}\text { Crown leaf width at the petiole } \\
\text { insertion }(\mathrm{cm})\end{array}$ & $\mathrm{C} 13$ & 15.4 & 13.4 & 17.4 & 14.9 & 12.1 & 17.2 & 15.0 & 9.5 & 17.4 & 16.4 & 11.9 & 19.0 & 17.70 \\
\hline Crown leaf maximum width $(\mathrm{cm})$ & $\mathrm{C} 14$ & 18.1 & 16.6 & 19.8 & 17.1 & 14.7 & 19.1 & 16.8 & 11.0 & 19.4 & 18.8 & 14.1 & 20.9 & 20.0 \\
\hline $\begin{array}{l}\text { Crown leaf distance of the } \\
\text { maximum width point }(\mathrm{cm})\end{array}$ & $\mathrm{C} 15$ & 8.14 & 8.02 & 8.28 & 7.41 & 6.57 & 8.51 & 7.13 & 5.04 & 8.80 & 7.78 & 5.74 & 8.67 & 8.41 \\
\hline
\end{tabular}




\begin{tabular}{|c|c|c|c|c|c|c|c|c|c|c|c|c|c|c|}
\hline Crown leaf apex angle (degrees) & $\mathrm{C} 16$ & 67.6 & 64.0 & 69.9 & 61.5 & 41.0 & 77.5 & 68.5 & 56.5 & 77.8 & 73.1 & 53.7 & 82.8 & 83.8 \\
\hline Crown leaf petiole length $(\mathrm{cm})$ & $\mathrm{C} 17$ & 8.32 & 7.18 & 9.05 & 8.15 & 7.26 & 8.83 & 7.40 & 6.02 & 8.45 & 8.86 & 8.10 & 9.44 & 9.88 \\
\hline \multicolumn{15}{|c|}{ Inflorescence and flower } \\
\hline Inflorescence length $(\mathrm{cm})$ & $\mathrm{C} 18$ & 8.45 & 7.67 & 9.56 & 8.27 & 7.44 & 9.15 & 8.00 & 7.29 & 8.40 & 8.10 & 7.73 & 8.70 & 4.73 \\
\hline Inflorescence peduncle length $(\mathrm{cm})$ & C19 & 3.87 & 3.12 & 4.93 & 3.68 & 2.76 & 4.47 & 3.36 & 3.14 & 3.64 & 3.71 & 3.46 & 3.88 & 1.62 \\
\hline $\begin{array}{l}\text { Inflorescence rachis internode length } \\
(\mathrm{cm})\end{array}$ & $\mathrm{C} 20$ & 2.43 & 2.18 & 2.77 & 2.25 & 2.03 & 2.59 & 2.22 & 1.94 & 2.33 & 2.19 & 2.01 & 2.38 & 1.61 \\
\hline Petal length (cm) & $\mathrm{C} 21$ & 1.21 & 1.16 & 1.25 & 1.20 & 1.11 & 1.26 & 1.21 & 1.05 & 1.32 & 1.18 & 1.07 & 1.24 & 1.00 \\
\hline Petal width (cm) & $\mathrm{C} 22$ & 0.49 & 0.44 & 0.53 & 0.47 & 0.42 & 0.56 & 0.49 & 0.44 & 0.53 & 0.51 & 0.47 & 0.53 & 0.45 \\
\hline Corolla diameter $(\mathrm{cm})$ & $\mathrm{C} 23$ & 2.43 & 2.32 & 2.50 & 2.40 & 2.21 & 2.57 & 2.43 & 2.10 & 2.64 & 2.36 & 2.14 & 2.47 & 2.01 \\
\hline Anther length $(\mathrm{cm})$ & $\mathrm{C} 24$ & 0.60 & 0.58 & 0.63 & 0.57 & 0.51 & 0.66 & 0.59 & 0.55 & 0.62 & 0.57 & 0.55 & 0.59 & 0.48 \\
\hline Style length $(\mathrm{cm})$ & $\mathrm{C} 25$ & 0.61 & 0.60 & 0.63 & 0.60 & 0.57 & 0.69 & 0.59 & 0.54 & 0.62 & 0.57 & 0.54 & 0.58 & 0.48 \\
\hline \multicolumn{15}{|c|}{ Infructescence and fruit } \\
\hline Fruits per plant & $\mathrm{C} 26$ & 36.1 & 31.8 & 38.4 & 40.6 & 20.5 & 60.7 & 34.6 & 20.3 & 54.1 & 22.6 & 18.3 & 26.9 & 160.0 \\
\hline Infructescences per plant & $\mathrm{C} 27$ & 14.0 & 13.2 & 14.7 & 14.3 & 7.2 & 20.6 & 14.5 & 9.5 & 22.1 & 10.6 & 8.1 & 12.5 & 10.0 \\
\hline Fruits per infructescence & $\mathrm{C} 28$ & 2.59 & 2.27 & 2.91 & 2.89 & 2.10 & 3.92 & 2.36 & 2.13 & 2.61 & 2.15 & 1.98 & 2.26 & 16.00 \\
\hline Fruit length $(\mathrm{cm})$ & $\mathrm{C} 29$ & 6.30 & 6.02 & 6.75 & 6.29 & 5.50 & 7.49 & 6.57 & 5.56 & 7.92 & 7.53 & 7.36 & 7.62 & 3.98 \\
\hline Fruit maximum width distance $(\mathrm{cm})$ & $\mathrm{C} 30$ & 2.78 & 2.63 & 2.97 & 2.68 & 2.43 & 3.05 & 2.82 & 2.45 & 3.25 & 3.11 & 3.00 & 3.23 & 1.60 \\
\hline Fruit pedicel length $(\mathrm{cm})$ & $\mathrm{C} 31$ & 4.72 & 4.21 & 5.21 & 4.66 & 3.96 & 5.12 & 4.92 & 4.52 & 5.14 & 5.07 & 4.49 & 5.91 & 3.91 \\
\hline Fruit width $(\mathrm{cm})$ & $\mathrm{C} 32$ & 5.17 & 5.00 & 5.44 & 4.59 & 4.04 & 5.88 & 5.23 & 4.68 & 5.96 & 5.56 & 5.49 & 5.64 & 3.74 \\
\hline Fruit apex angle (degrees) & $\mathrm{C} 33$ & 132.4 & 130.7 & 134.4 & 124.0 & 118.8 & 129.4 & 132.7 & 130.3 & 134.7 & 127.9 & 125.4 & 129.6 & 123.4 \\
\hline Fruit weight $(\mathrm{g})$ & C34 & 92.7 & 83.5 & 98.2 & 75.1 & 50.7 & 139.2 & 108.8 & 75.8 & 154.2 & 127.7 & 123.4 & 131.6 & 30.5 \\
\hline Fruit length/width ratio & $\mathrm{C} 35$ & 1.22 & 1.13 & 1.33 & 1.37 & 1.23 & 1.48 & 1.25 & 1.18 & 1.33 & 1.36 & 1.34 & 1.38 & 1.06 \\
\hline Fruit length/maximum width distance & $\mathrm{C} 36$ & 2.26 & 2.23 & 2.29 & 2.34 & 2.18 & 2.46 & 2.32 & 2.21 & 2.44 & 2.42 & 2.36 & 2.45 & 2.50 \\
\hline ratio & & & & & & & & & & & & & & \\
\hline \multicolumn{15}{|c|}{ Seed } \\
\hline Seed length $(\mathrm{cm})$ & C37 & 0.39 & 0.37 & 0.40 & 3.80 & 0.34 & 0.41 & 0.38 & 0.35 & 0.40 & 0.38 & 0.37 & 0.39 & 0.42 \\
\hline Seed width $(\mathrm{cm})$ & $\mathrm{C} 38$ & 0.32 & 0.31 & 0.32 & 3.20 & 0.28 & 0.34 & 0.31 & 0.29 & 0.32 & 0.31 & 0.30 & 0.31 & 0.32 \\
\hline Seeds per fruit & C39 & 259.9 & 239.8 & 272.8 & 192.0 & 124.5 & 352.6 & 317.9 & 245.1 & 382.2 & 343.7 & 312.8 & 369.5 & 3.4 \\
\hline
\end{tabular}


Table 5. Pearson linear correlation coefficients between descriptors studied ( $\mathrm{C}$ codes; see

Table 2 for full description) and for which at least one correlation was significant (values in bold) according to the Bonferroni test $(\mathrm{P} \leq 0.05 ; \mathrm{r} \geq 0.78)$. Horizontal and vertical lines separate correlations corresponding to descriptors from the same part of the plant (above) from those corresponding to correlations between descriptors from different parts of the plant (below).

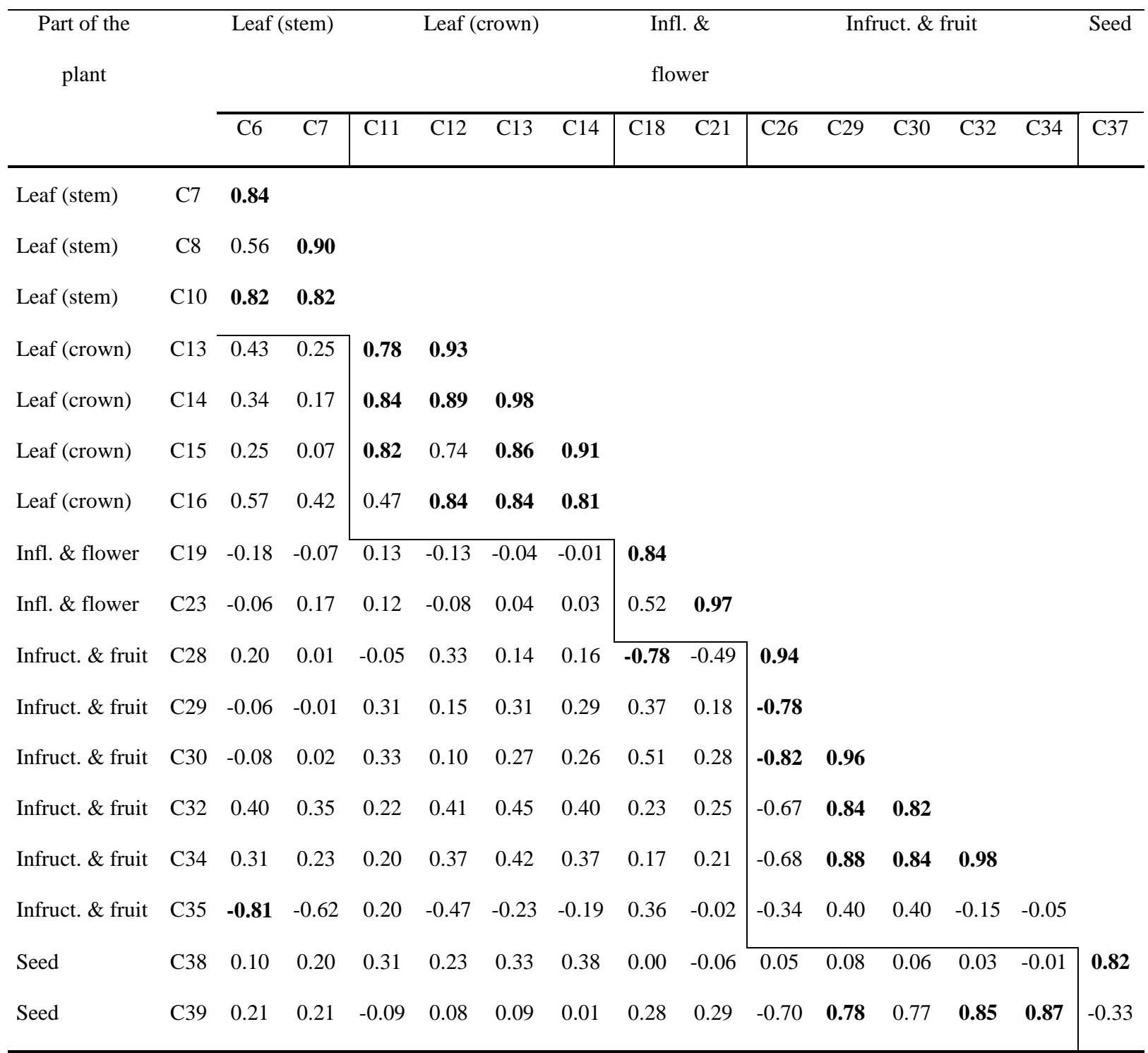




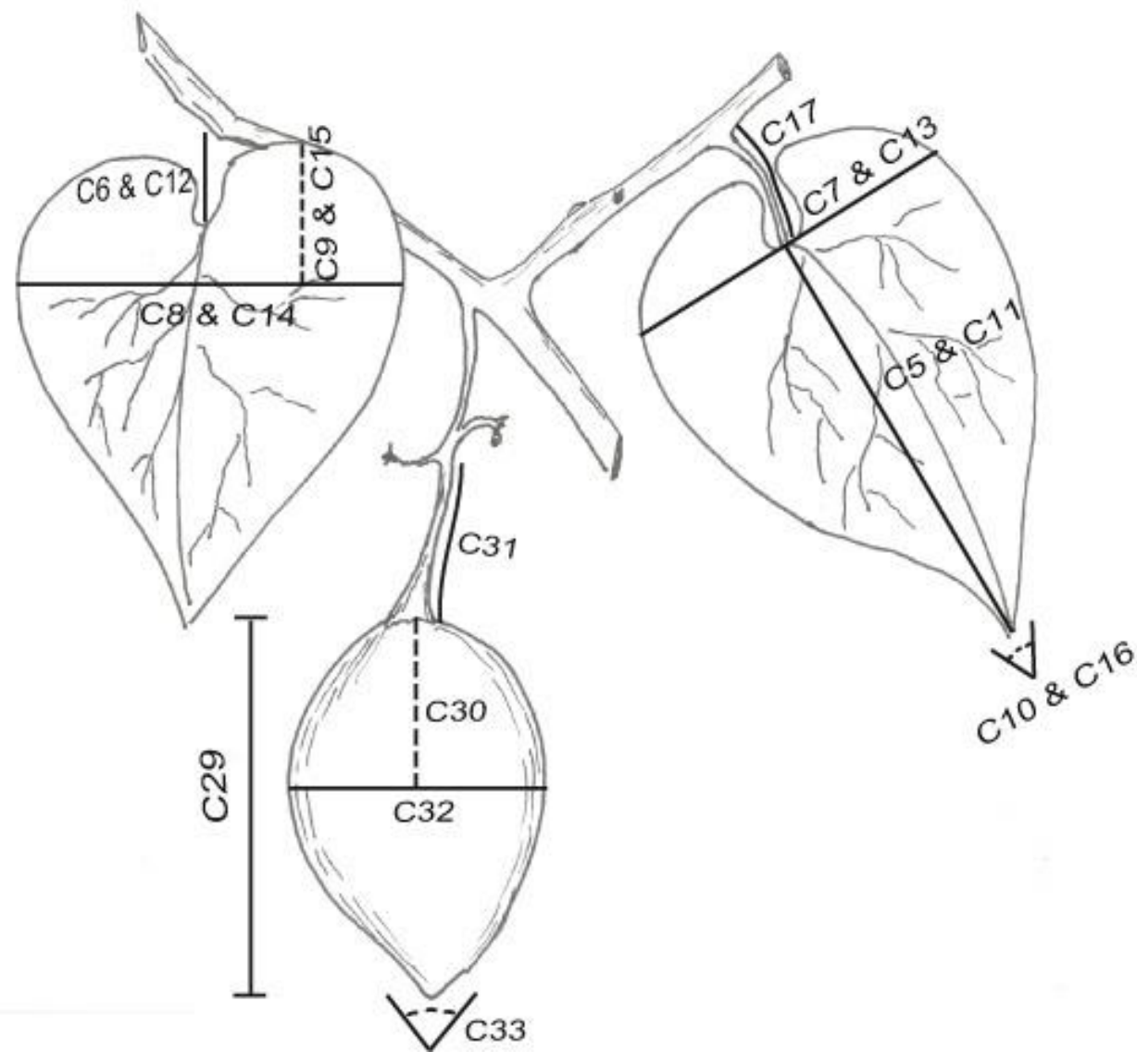

Figure 1. Descriptors evaluated in tree tomato leaves and fruits. For stem and crown leaves the descriptors considered were: central nerve length (C5 \& C11), leaf lobules length (C6 $\& \mathrm{C} 12)$, leaf width at the petiole insertion (C7 \& C13), leaf maximum width (C8 \& C14), leaf distance of the maximum width point $(\mathrm{C} 9 \& \mathrm{C} 15)$, and leaf apex angle $(\mathrm{C} 10 \& \mathrm{C} 16)$; additionally, for crown leaves, the leaf petiole length (C17) was evaluated. For fruits the descriptors considered were: fruit length (C29), fruit maximum width distance (C30), fruit pedicel length (C31), fruit width (C32), and fruit apex angle (C33). 


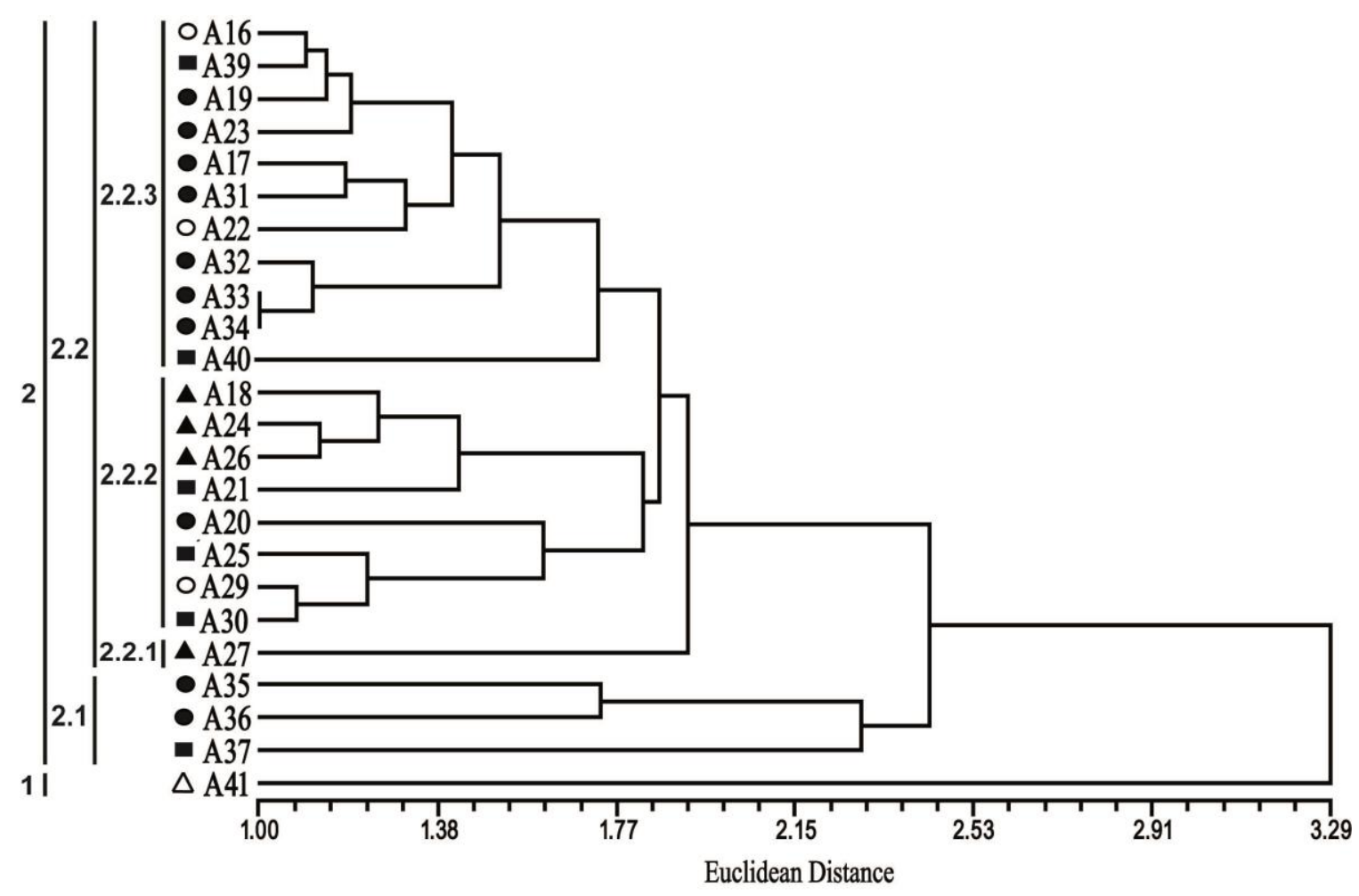

Figure 2. UPGMA phenogram of 24 accessions of tree tomato based on 39 quantitative descriptors. Phenetic relationships were based on Euclidean pairwise distance estimates. The different cultivar groups are indicaled: orarge, orange poin $\mathbf{d}, \quad$ pur $\mathbf{e}, \quad \operatorname{red}, \boldsymbol{\Delta}$ and red conical. 


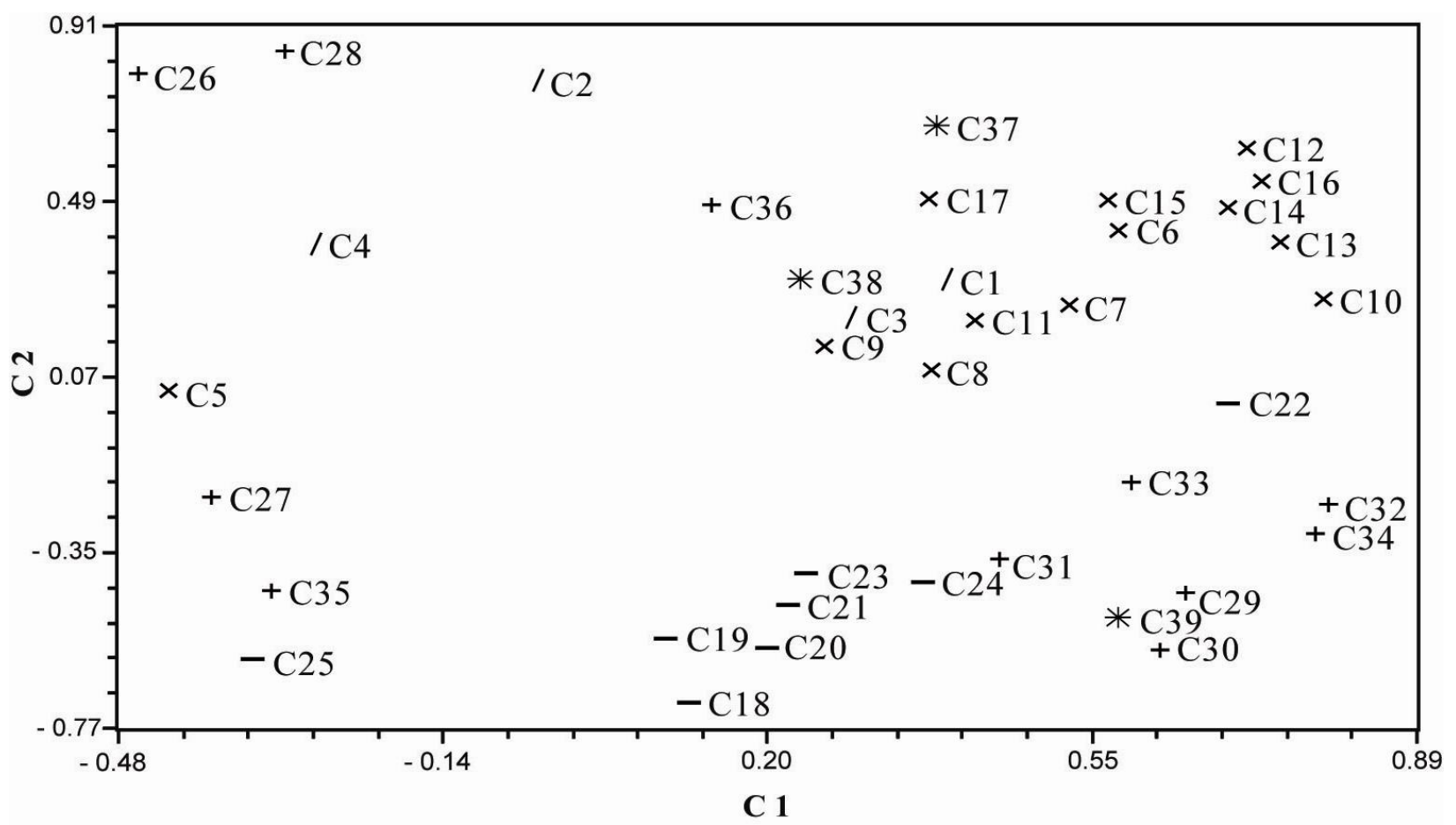

Figure 3. Relationships between the descriptors developed (see Table 2) resulting from the characterization of 24 accessions of tree tomato based on the two first components of PCA (25.33\% and $22.08 \%$ of the total variation, respectively). Different parts of the plant are represented by different symbols: plant architecture (/), leaf $(\times)$, inflorescence and flower $(-)$, infructescence and fruit (+), and seed (*). 


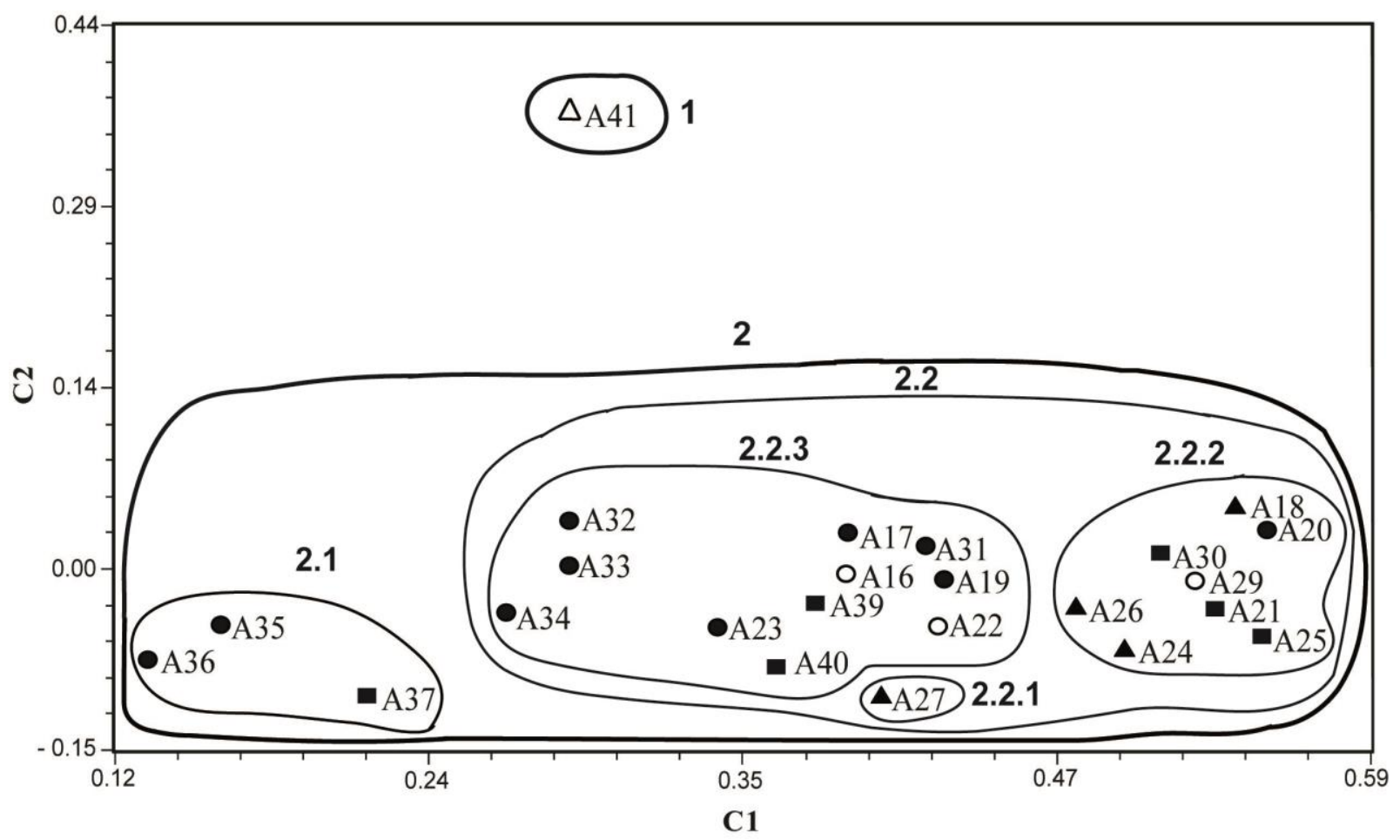

Figure 4. Morphological similarities based on 39 quantitative descriptors (Table 2) among the 24 accessions of tree tomato based on the two first components of PCA (25.33\% and $22.08 \%$ of the total variation, respectively) and grouping of the accessions according to the clusters considered in Figure 1. The different cultivar groups are indicated: orangeø orange pointed, - purple, $\boldsymbol{\Delta}$ red, and $\Delta$ red conical. 


\section{ELECTRONIC SUPPLEMENTARY MATERIAL}

Article title: Variation among tree tomato (Solanum betaceum Cav.) accessions from different cultivar groups: implications for conservation of genetic resources and breeding Journal name: Genetic Resources and Crop Evolution

Author names: Pablo G. Acosta-Quezada ${ }^{1}$, Juan B. Martínez-Laborde ${ }^{2}$, Jaime Prohens ${ }^{3}$ Affiliations: ${ }^{1}$ Centro de Investigación, Transferencia de Tecnología, Extensión y Servicios Agropecuarios, Universidad Técnica Particular de Loja, San Cayetano Alto s/n, 1101608 Loja, Ecuador

${ }^{2}$ Departamento de Biología Vegetal, Escuela Técnica Superior de Ingenieros Agrónomos, Universidad Politécnica de Madrid, Av. Complutense s/n, Ciudad Universitaria, 28040 Madrid, Spain

${ }^{3}$ Instituto de Conservación y Mejora de la Agrodiversidad Valenciana, Universidad Politécnica de Valencia, Camino de Vera 14, 46022 Valencia, Spain

E-mail address of corresponding author: jprohens@btc.upv.es 


\section{ANALYSIS OF VARIANCE (ANOVA) FOR THE TRAITS MEASURED}

Table S1. Analysis of variance for the 39 descriptors in the 24 tree tomato accessions studied.

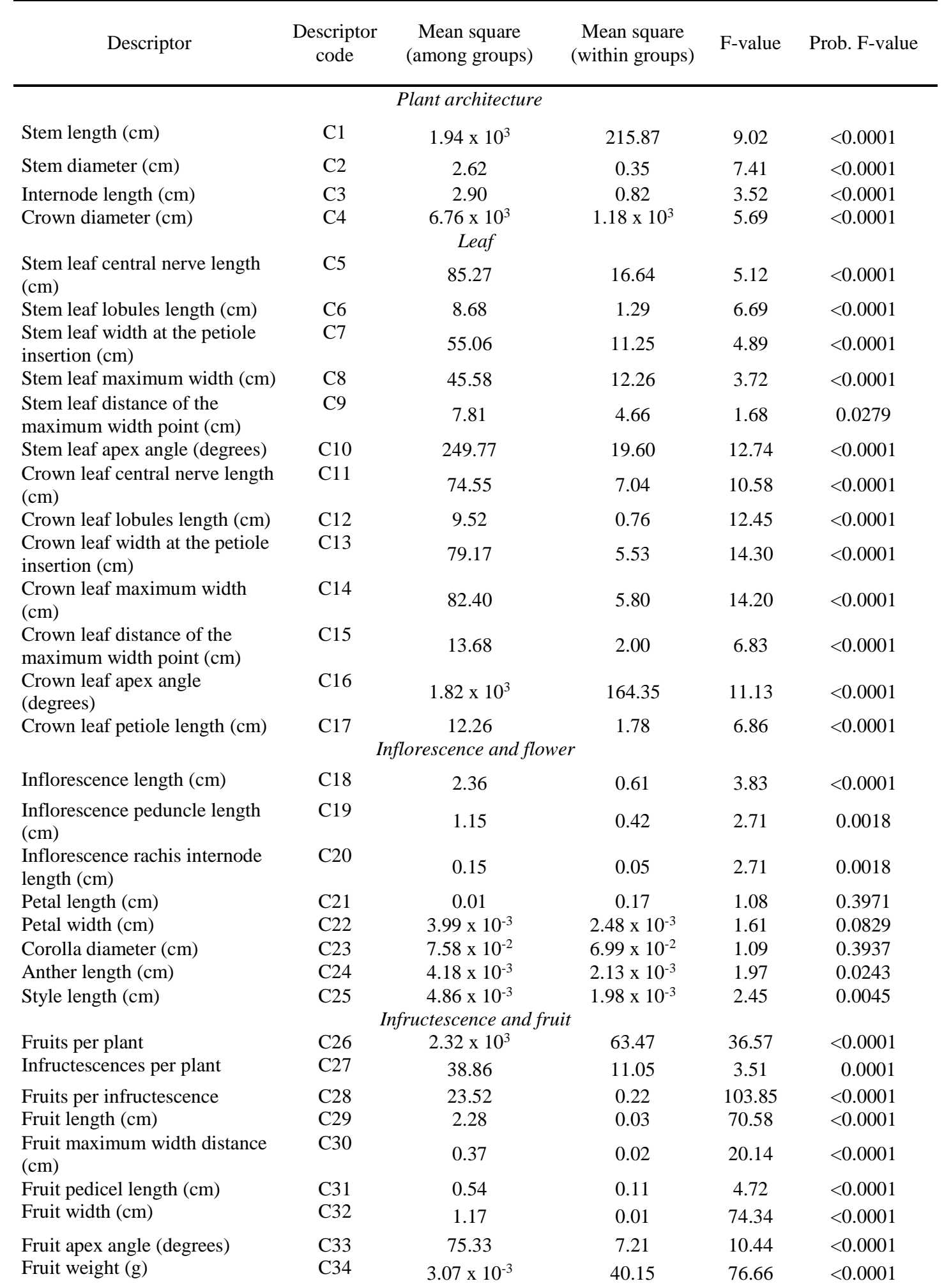


Fruit length/width ratio

Fruit length/maximum width

distance ratio

Seed length (mm)

Seed width (mm)

Seeds per fruit

\begin{tabular}{ccccc} 
C35 & 0.03 & 0.00 & 19.45 & $<0.0001$ \\
C36 & 0.02 & 0.01 & 1.96 & 0.0248 \\
& Seed & & & \\
C37 & $9.47 \times 10^{-4}$ & $1.33 \times 10^{-4}$ & 7.11 & $<0.0001$ \\
C38 & $6.04 \times 10^{-4}$ & $6.81 \times 10^{-5}$ & 8.88 & $<0.0001$ \\
C39 & $2.99 \times 10^{4}$ & $1.08 \times 10^{3}$ & 27.53 & $<0.0001$ \\
\hline
\end{tabular}




\section{MEANS AND MEAN SEPARATION FOR THE TRAITS MEASURED}

\section{Plant architecture}

Table S2. Means and multiple comparison among mean differences for the 24 accessions for the plant architecture traits studied.

\begin{tabular}{|c|c|c|c|c|c|c|c|c|c|c|c|c|c|c|c|c|c|c|c|c|}
\hline \multirow{2}{*}{$\frac{\text { Accession }}{\text { A16 }}$} & \multicolumn{7}{|c|}{$\begin{array}{l}\text { Stem length } \\
(\mathrm{cm} ; \mathrm{C} 1)\end{array}$} & \multicolumn{5}{|c|}{$\begin{array}{c}\text { Stem diameter } \\
(\mathrm{cm} ; \mathrm{C} 2)\end{array}$} & \multicolumn{2}{|c|}{$\begin{array}{l}\text { Internode length } \\
(\mathrm{cm} ; \mathrm{C} 3)\end{array}$} & \multicolumn{6}{|c|}{$\begin{array}{c}\text { Crown diameter } \\
(\mathrm{cm} ; \mathrm{C} 4)\end{array}$} \\
\hline & 127.67 & $\mathrm{a}$ & $\mathrm{b}$ & $\mathrm{c}$ & & & & 3.59 & & $\mathrm{~b}$ & c d & $\mathrm{e}$ & 4.52 & $\mathrm{a}$ & 132.67 & $\mathrm{~b}$ & $\mathrm{c}$ & d & $\mathrm{e}$ & $\mathrm{f}$ \\
\hline A17 & 128.47 & $\mathrm{a}$ & $\mathrm{b}$ & $\mathrm{c}$ & & & & 3.61 & & $\mathrm{~b}$ & c d & $\mathrm{e}$ & 3.83 & $\mathrm{a}$ & 112.00 & $\mathrm{a} \quad \mathrm{b}$ & $\mathrm{c}$ & $d$ & $\mathrm{e}$ & $\mathrm{f}$ \\
\hline A18 & 143.47 & & & c d & $\mathrm{d}$ & $\mathrm{e}$ & & 3.52 & & $\mathrm{~b}$ & c d & $\mathrm{e}$ & 4.17 & $\mathrm{a}$ & 147.88 & & & & $\mathrm{e}$ & f \\
\hline A19 & 144.73 & & & c d & d & e & & 3.28 & & $\mathrm{~b}$ & c d & & 4.31 & $\mathrm{a}$ & 130.33 & $\mathrm{~b}$ & $\mathrm{c}$ & d & $\mathrm{e}$ & $\mathrm{f}$ \\
\hline $\mathrm{A} 20$ & 148.32 & & & & $\mathrm{~d}$ & e $\mathrm{f}$ & & 4.06 & & & & $\mathrm{e}$ & 5.74 & $\mathrm{~b}$ & 159.00 & & & & & f \\
\hline A21 & 138.20 & & $\mathrm{~b}$ & $\mathrm{c} \quad \mathrm{d}$ & $\mathrm{d}$ & $\mathrm{e}$ & & 3.03 & $\mathrm{a}$ & $\mathrm{b}$ & $\mathrm{c}$ & & 4.51 & $\mathrm{a}$ & 96.90 & $\mathrm{a} \quad \mathrm{b}$ & & & & \\
\hline A22 & 132.79 & $\mathrm{a}$ & $\mathrm{b}$ & $c d$ & $\mathrm{~d}$ & & & 3.29 & & $\mathrm{~b}$ & $\mathrm{c} \quad \mathrm{d}$ & & 4.63 & $\mathrm{a}$ & 98.64 & a b & $\mathrm{c}$ & & & \\
\hline A23 & 137.67 & & $\mathrm{~b}$ & $c \quad d$ & d & $\mathrm{e}$ & & 3.38 & & $\mathrm{~b}$ & c d & $\mathrm{e}$ & 3.88 & $\mathrm{a}$ & 114.50 & a b & $\mathrm{c}$ & $d$ & $\mathrm{e}$ & $\mathrm{f}$ \\
\hline A24 & 129.64 & $\mathrm{a}$ & $\mathrm{b}$ & $\mathrm{c}$ & & & & 3.09 & $\mathrm{a}$ & $\mathrm{b}$ & c d & & 3.99 & $\mathrm{a}$ & 116.64 & $\mathrm{a} \quad \mathrm{b}$ & $\mathrm{c}$ & $d$ & $\mathrm{e}$ & $\mathrm{f}$ \\
\hline A 25 & 130.93 & $\mathrm{a}$ & $\mathrm{b}$ & c d & $\mathrm{d}$ & & & 3.56 & & $\mathrm{~b}$ & c d & $\mathrm{e}$ & 4.01 & $\mathrm{a}$ & 124.33 & $\mathrm{a} \quad \mathrm{b}$ & $\mathrm{c}$ & $d$ & $\mathrm{e}$ & f \\
\hline A26 & 140.41 & & & $\mathrm{c} \quad \mathrm{d}$ & $\mathrm{d}$ & $\mathrm{e}$ & & 2.86 & $\mathrm{a}$ & $\mathrm{b}$ & & & 3.70 & $\mathrm{a}$ & 116.00 & $\mathrm{a} \quad \mathrm{b}$ & $\mathrm{c}$ & d & $\mathrm{e}$ & $\mathrm{f}$ \\
\hline A27 & 134.92 & & $\mathrm{~b}$ & $\mathrm{c} \quad \mathrm{d}$ & d & $\mathrm{e}$ & & 3.11 & $\mathrm{a}$ & $\mathrm{b}$ & c d & & 3.92 & $\mathrm{a}$ & 118.00 & $\mathrm{a} \quad \mathrm{b}$ & $\mathrm{c}$ & d & $\mathrm{e}$ & f \\
\hline A29 & 163.36 & & & & & & $\mathrm{~g}$ & 3.59 & & $\mathrm{~b}$ & c d & $\mathrm{e}$ & 4.46 & $\mathrm{a}$ & 102.36 & $\mathrm{a} \quad \mathrm{b}$ & $\mathrm{c}$ & $d$ & & \\
\hline A30 & 160.13 & & & & & $\mathrm{f}$ & $\mathrm{f}$ & 3.71 & & & c d & $\mathrm{e}$ & 4.49 & $\mathrm{a}$ & 115.53 & $\mathrm{~b}$ & $\mathrm{c}$ & d & $\mathrm{e}$ & $\mathrm{f}$ \\
\hline A31 & 140.00 & & & c d & d & $\mathrm{e}$ & & 3.34 & & $\mathrm{~b}$ & c d & $\mathrm{e}$ & 3.74 & $\mathrm{a}$ & 118.79 & a b & $\mathrm{c}$ & d & $\mathrm{e}$ & f \\
\hline A32 & 129.36 & $\mathrm{a}$ & $\mathrm{b}$ & $\mathrm{c}$ & & & & 3.85 & & & $\mathrm{~d}$ & $\mathrm{e}$ & 4.54 & $\mathrm{a}$ & 139.36 & $\mathrm{~b}$ & $\mathrm{c}$ & $d$ & $\mathrm{e}$ & $\mathrm{f}$ \\
\hline A33 & 120.33 & $\mathrm{a}$ & $\mathrm{b}$ & & & & & 3.43 & & $\mathrm{~b}$ & c d & $\mathrm{e}$ & 3.98 & $\mathrm{a}$ & 153.07 & & & & $\mathrm{e}$ & $\mathrm{f}$ \\
\hline A34 & 127.47 & $\mathrm{a}$ & $\mathrm{b}$ & $\mathrm{c}$ & & & & 3.55 & & $\mathrm{~b}$ & c d & $\mathrm{e}$ & 4.12 & a & 155.13 & & & & $\mathrm{e}$ & $\mathrm{f}$ \\
\hline A35 & 137.47 & & $\mathrm{~b}$ & $c \quad d$ & d & $\mathrm{e}$ & & 3.39 & & $\mathrm{~b}$ & c d & $\mathrm{e}$ & 4.49 & $\mathrm{a}$ & 158.00 & & & & & $\mathrm{f}$ \\
\hline A36 & 116.27 & $\mathrm{a}$ & & & & & & 3.01 & $\mathrm{a}$ & $\mathrm{b}$ & $\mathrm{c}$ & & 3.57 & $\mathrm{a}$ & 122.87 & $\mathrm{~b}$ & $\mathrm{c}$ & $d$ & $\mathrm{e}$ & $\mathrm{f}$ \\
\hline A37 & 151.40 & & & & & e $\mathrm{f}$ & $\mathrm{f}$ & 3.54 & & $\mathrm{~b}$ & $\mathrm{c} \quad \mathrm{d}$ & $\mathrm{e}$ & 4.14 & $\mathrm{a}$ & 115.80 & $\mathrm{a} \quad \mathrm{b}$ & $\mathrm{c}$ & d & $\mathrm{e}$ & f \\
\hline A39 & 130.58 & $\mathrm{a}$ & $\mathrm{b}$ & $\mathrm{c} \quad \mathrm{d}$ & d & & & 3.43 & & $\mathrm{~b}$ & c d & $\mathrm{e}$ & 4.37 & $\mathrm{a}$ & 142.00 & & $\mathrm{c}$ & d & $\mathrm{e}$ & f \\
\hline A40 & 130.20 & $\mathrm{a}$ & $\mathrm{b}$ & $\mathrm{c} \quad \mathrm{d}$ & d & & & 2.60 & $\mathrm{a}$ & & & & 4.40 & $\mathrm{a}$ & 77.47 & $\mathrm{a}$ & & & & \\
\hline A41 & 145.93 & & & $\mathrm{c} \quad \mathrm{d}$ & $\mathrm{d}$ & $\mathrm{e}$ & & 4.70 & & & & $\mathrm{f}$ & 4.25 & $\mathrm{a}$ & 144.28 & & & $\mathrm{~d}$ & $\mathrm{e}$ & $\mathrm{f}$ \\
\hline Mean & 137.07 & & & & & 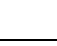 & & 3.44 & & & 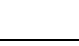 & 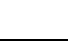 & 4.24 & & 125.48 & 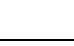 & 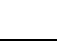 & 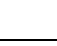 & & \\
\hline
\end{tabular}




\section{Stem leaf}

Table S3. Means and multiple comparison among mean differences for the 24 accessions for the stem leaf traits studied.

\begin{tabular}{|c|c|c|c|c|c|c|c|c|c|c|c|c|c|c|c|c|c|c|c|c|c|c|c|c|c|c|}
\hline \multirow{2}{*}{$\begin{array}{c}\text { Accession } \\
\text { A-16 }\end{array}$} & \multicolumn{4}{|c|}{$\begin{array}{c}\text { Stem leaf central nerve } \\
\text { length } \\
(\mathrm{cm} ; \mathrm{C} 5)\end{array}$} & \multicolumn{7}{|c|}{$\begin{array}{l}\text { Stem leaf lobules length } \\
(\mathrm{cm} ; \mathrm{C} 6)\end{array}$} & \multicolumn{5}{|c|}{$\begin{array}{l}\text { Stem leaf width at the } \\
\text { petiole insertion } \\
(\mathrm{cm} ; \mathrm{C} 7)\end{array}$} & \multicolumn{4}{|c|}{$\begin{array}{c}\text { Stem leaf maximum } \\
\text { width } \\
(\mathrm{cm} ; \mathrm{C} 8)\end{array}$} & \multicolumn{3}{|c|}{$\begin{array}{l}\text { Stem leaf distance } \\
\text { of the maximum } \\
\text { width point } \\
(\mathrm{cm} ; \mathrm{C} 9)\end{array}$} & \multicolumn{3}{|c|}{$\begin{array}{l}\text { Stem leaf apex angle } \\
\text { (degrees; } \mathrm{C} 10)\end{array}$} \\
\hline & 31.77 & & $\mathrm{c}$ & d & 6.47 & & & $\mathrm{c}$ & $\mathrm{d}$ & $\mathrm{e}$ & $\mathrm{f}$ & 25.16 & & & & d & 27.36 & & & $\mathrm{c}$ & 12.30 & $\mathrm{a}$ & $\mathrm{b}$ & 77.11 & $\mathrm{~b}$ & c \\
\hline A-17 & 29.38 & $\mathrm{~b}$ & $\mathrm{c}$ & $\mathrm{d}$ & 5.50 & & $\mathrm{~b}$ & $\mathrm{c}$ & d & $\mathrm{e}$ & $\mathrm{f}$ & 22.10 & & & $\mathrm{c}$ & d & 24.13 & $\mathrm{a}$ & $\mathrm{b}$ & $\mathrm{c}$ & 11.81 & a & $\mathrm{b}$ & 76.19 & $\mathrm{~b}$ & c \\
\hline A- 18 & 27.03 & $\mathrm{~b}$ & $\mathrm{c}$ & & 6.34 & & & $\mathrm{c}$ & d & $\mathrm{e}$ & $\mathrm{f}$ & 22.89 & & & $\mathrm{c}$ & d & 24.93 & $\mathrm{a}$ & $\mathrm{b}$ & $\mathrm{c}$ & 11.31 & $\mathrm{a}$ & $\mathrm{b}$ & 79.67 & & c \\
\hline A-19 & 31.40 & $\mathrm{~b}$ & $c$ & $\mathrm{~d}$ & 5.87 & & $\mathrm{~b}$ & $\mathrm{c}$ & d & $\mathrm{e}$ & $\mathrm{f}$ & 24.66 & & & $\mathrm{c}$ & d & 27.70 & & & $\mathrm{c}$ & 11.42 & $\mathrm{a}$ & $\mathrm{b}$ & 81.63 & & c \\
\hline A-20 & 30.54 & $\mathrm{~b}$ & $\mathrm{c}$ & $\mathrm{d}$ & 6.20 & & & $\mathrm{c}$ & $\mathrm{d}$ & $\mathrm{e}$ & $\mathrm{f}$ & 24.62 & & & $\mathrm{c}$ & $\mathrm{d}$ & 26.91 & & & $\mathrm{c}$ & 12.42 & $\mathrm{a}$ & $\mathrm{b}$ & 80.97 & & c \\
\hline A- 21 & 22.37 & $\mathrm{a}$ & & & 6.17 & & & $\mathrm{c}$ & d & $\mathrm{e}$ & $\mathrm{f}$ & 20.53 & $\mathrm{a}$ & $\mathrm{b}$ & $\mathrm{c}$ & & 21.75 & $\mathrm{a}$ & $\mathrm{b}$ & & 10.16 & a & $\mathrm{b}$ & 76.16 & $\mathrm{~b}$ & c \\
\hline A- 22 & 29.07 & $\mathrm{~b}$ & $\mathrm{c}$ & & 5.21 & & $\mathrm{~b}$ & $\mathrm{c}$ & d & & & 21.86 & & $\mathrm{~b}$ & $\mathrm{c}$ & $\mathrm{d}$ & 24.37 & $\mathrm{a}$ & $\mathrm{b}$ & $\mathrm{c}$ & 10.84 & a & $\mathrm{b}$ & 77.14 & $\mathrm{~b}$ & c \\
\hline A- 23 & 29.95 & $\mathrm{~b}$ & $\mathrm{c}$ & $\mathrm{d}$ & 6.34 & & & $\mathrm{c}$ & d & $\mathrm{e}$ & $\mathrm{f}$ & 24.29 & & & $\mathrm{c}$ & d & 26.46 & & & $\mathrm{c}$ & 11.71 & $\mathrm{a}$ & $\mathrm{b}$ & 78.01 & $\mathrm{~b}$ & c \\
\hline A- 24 & 26.21 & $\mathrm{~b}$ & & & 5.36 & & $\mathrm{~b}$ & $\mathrm{c}$ & d & $\mathrm{e}$ & & 21.20 & a & $\mathrm{b}$ & $\mathrm{c}$ & d & 23.15 & $\mathrm{a}$ & b & $\mathrm{c}$ & 10.16 & $\mathrm{a}$ & b & 78.02 & $\mathrm{~b}$ & c \\
\hline A- 25 & 29.88 & $\mathrm{~b}$ & $\mathrm{c}$ & $\mathrm{d}$ & 6.61 & & & & $\mathrm{~d}$ & $\mathrm{e}$ & $\mathrm{f}$ & 25.28 & & & & $\mathrm{~d}$ & 27.18 & & & $\mathrm{c}$ & 11.40 & $\mathrm{a}$ & $\mathrm{b}$ & 80.74 & & c \\
\hline A- 26 & 28.82 & $\mathrm{~b}$ & $\mathrm{c}$ & & 5.70 & & $\mathrm{~b}$ & $\mathrm{c}$ & $\mathrm{d}$ & e & $\mathrm{f}$ & 22.38 & & & $\mathrm{c}$ & $\mathrm{d}$ & 24.74 & $\mathrm{a}$ & $\mathrm{b}$ & $\mathrm{c}$ & 11.40 & a & b & 76.69 & $\mathrm{~b}$ & c \\
\hline A-27 & 28.28 & $\mathrm{~b}$ & $\mathrm{c}$ & & 5.61 & & $\mathrm{~b}$ & $\mathrm{c}$ & $\mathrm{d}$ & $\mathrm{e}$ & $\mathrm{f}$ & 23.08 & & & $\mathrm{c}$ & $d$ & 25.15 & & $\mathrm{~b}$ & $\mathrm{c}$ & 11.25 & $\mathrm{a}$ & $\mathrm{b}$ & 80.05 & & c \\
\hline A- 29 & 29.20 & $\mathrm{~b}$ & $\mathrm{c}$ & $\mathrm{d}$ & 6.78 & & & & & e & $\mathrm{f}$ & 24.66 & & & $\mathrm{c}$ & $\mathrm{d}$ & 26.30 & & & $\mathrm{c}$ & 12.00 & $\mathrm{a}$ & b & 81.71 & & c \\
\hline A- 30 & 31.40 & $\mathrm{~b}$ & $\mathrm{c}$ & $\mathrm{d}$ & 6.59 & & & & d & e & $\mathrm{f}$ & 24.61 & & & $\mathrm{c}$ & $\mathrm{d}$ & 27.22 & & & $\mathrm{c}$ & 12.49 & & $\mathrm{~b}$ & 80.48 & & c \\
\hline A-31 & 28.60 & $\mathrm{~b}$ & $\mathrm{c}$ & & 5.81 & & $\mathrm{~b}$ & $\mathrm{c}$ & $\mathrm{d}$ & $\mathrm{e}$ & $\mathrm{f}$ & 22.23 & & & $\mathrm{c}$ & $\mathrm{d}$ & 24.53 & $\mathrm{a}$ & $\mathrm{b}$ & $\mathrm{c}$ & 10.81 & $\mathrm{a}$ & $\mathrm{b}$ & 78.24 & $\mathrm{~b}$ & c \\
\hline A-32 & 32.22 & & $\mathrm{c}$ & $\mathrm{d}$ & 5.83 & & $\mathrm{~b}$ & $\mathrm{c}$ & $\mathrm{d}$ & e & $\mathrm{f}$ & 23.63 & & & $\mathrm{c}$ & $\mathrm{d}$ & 26.35 & & & $\mathrm{c}$ & 11.10 & $\mathrm{a}$ & $\mathrm{b}$ & 74.04 & $\mathrm{~b}$ & \\
\hline A-33 & 32.16 & & $\mathrm{c}$ & $\mathrm{d}$ & 5.02 & & $\mathrm{~b}$ & $\mathrm{c}$ & & & & 21.79 & & $\mathrm{~b}$ & $\mathrm{c}$ & $\mathrm{d}$ & 25.05 & $\mathrm{a}$ & $\mathrm{b}$ & $\mathrm{c}$ & 11.07 & $\mathrm{a}$ & $\mathrm{b}$ & 73.60 & $\mathrm{~b}$ & \\
\hline A-34 & 30.77 & $\mathrm{~b}$ & $\mathrm{c}$ & $\mathrm{d}$ & 5.09 & & $\mathrm{~b}$ & $\mathrm{c}$ & & & & 21.28 & $\mathrm{a}$ & $\mathrm{b}$ & $\mathrm{c}$ & $\mathrm{d}$ & 24.33 & $\mathrm{a}$ & $\mathrm{b}$ & $\mathrm{c}$ & 11.27 & $\mathrm{a}$ & $\mathrm{b}$ & 73.38 & $\mathrm{~b}$ & \\
\hline A-35 & 34.28 & & & $\mathrm{~d}$ & 3.73 & $\mathrm{a}$ & & & & & & 18.02 & $\mathrm{a}$ & & & & 23.08 & $\mathrm{a}$ & $\mathrm{b}$ & $\mathrm{c}$ & 11.88 & $\mathrm{a}$ & $\mathrm{b}$ & 65.28 & $\mathrm{a}$ & \\
\hline A-36 & 28.10 & $\mathrm{~b}$ & $\mathrm{c}$ & & 4.52 & $\mathrm{a}$ & $\mathrm{b}$ & & & & & 18.40 & $\mathrm{a}$ & $\mathrm{b}$ & & & 20.78 & $\mathrm{a}$ & & & 9.56 & $\mathrm{a}$ & & 67.87 & $\mathrm{a}$ & \\
\hline A-37 & 31.85 & & $\mathrm{c}$ & $\mathrm{d}$ & 5.76 & & $\mathrm{~b}$ & $\mathrm{c}$ & d & $\mathrm{e}$ & $\mathrm{f}$ & 22.96 & & & $\mathrm{c}$ & d & 25.31 & & $\mathrm{~b}$ & $\mathrm{c}$ & 11.06 & $\mathrm{a}$ & $\mathrm{b}$ & 73.40 & $\mathrm{~b}$ & \\
\hline A-39 & 29.28 & $\mathrm{~b}$ & $\mathrm{c}$ & $\mathrm{d}$ & 6.22 & & & $\mathrm{c}$ & $\mathrm{d}$ & e & $\mathrm{f}$ & 22.77 & & & $\mathrm{c}$ & $\mathrm{d}$ & 24.90 & $\mathrm{a}$ & $\mathrm{b}$ & $\mathrm{c}$ & 10.84 & $\mathrm{a}$ & $\mathrm{b}$ & 77.05 & $\mathrm{~b}$ & c \\
\hline A- 40 & 29.53 & $\mathrm{~b}$ & $\mathrm{c}$ & $\mathrm{d}$ & 6.57 & & & & $\mathrm{~d}$ & e & $\mathrm{f}$ & 23.46 & & & $\mathrm{c}$ & $\mathrm{d}$ & 24.67 & $\mathrm{a}$ & $\mathrm{b}$ & $\mathrm{c}$ & 10.56 & $\mathrm{a}$ & $\mathrm{b}$ & 78.18 & $\mathrm{~b}$ & c \\
\hline A-41 & 29.27 & $\mathrm{~b}$ & $\mathrm{c}$ & $\mathrm{d}$ & 6.95 & & & & & & $\mathrm{f}$ & 23.67 & & & $\mathrm{c}$ & d & 24.28 & $\mathrm{a}$ & $\mathrm{b}$ & $\mathrm{c}$ & 10.98 & $\mathrm{a}$ & $\mathrm{b}$ & 79.80 & & c \\
\hline Mean & 29.64 & & & & 5.84 & & & & & & & 22.73 & & & & & 25.02 & & & & 11.24 & & & 76.89 & & \\
\hline
\end{tabular}

Means within a column followed by different letters are significantly different $(\mathrm{P}<0.05)$ according to the Student-Newman-Keuls multiple range test . 


\section{Crown leaf}

Table S4. Means and multiple comparison among mean differences for the 24 accessions for the crown leaf traits studied.

\begin{tabular}{|c|c|c|c|c|c|c|c|c|c|c|c|c|c|c|c|c|c|c|c|c|c|c|c|c|c|c|c|c|c|c|c|}
\hline \multirow{2}{*}{$\frac{\text { Accession }}{\text { A16 }}$} & \multicolumn{6}{|c|}{$\begin{array}{l}\text { Crown leaf central nerve length } \\
(\mathrm{cm} ; \mathrm{C} 11)\end{array}$} & \multicolumn{9}{|c|}{$\begin{array}{l}\text { Crown leaf lobules length } \\
(\mathrm{cm} ; \mathrm{C} 12)\end{array}$} & \multicolumn{8}{|c|}{$\begin{array}{l}\text { Crown leaf width at the petiole } \\
\text { insertion }(\mathrm{cm} ; \mathrm{C} 13)\end{array}$} & \multicolumn{8}{|c|}{$\begin{array}{l}\text { Crown leaf maximum width } \\
(\mathrm{cm} ; \mathrm{C} 14)\end{array}$} \\
\hline & 21.29 & & $\mathrm{c}$ & $\mathrm{d}$ & $\mathrm{e}$ & & 3.78 & & $\mathrm{~b} \quad \mathrm{c}$ & $\mathrm{c} \quad \mathrm{d}$ & $\mathrm{e}$ & & & & & 13.40 & $\mathrm{~b}$ & $\mathrm{c}$ & $\mathrm{d}$ & & & & & 16.64 & & $\mathrm{c}$ & & & & & \\
\hline A17 & 23.58 & & & & $\mathrm{e}$ & $\mathrm{f}$ & 4.56 & & & d & e & f & $\mathrm{g}$ & $\mathrm{h}$ & & 17.01 & & & & & f $g$ & $h$ & $\mathrm{i}$ & 19.09 & & & & & f $g$ & $\mathrm{~g} h$ & $\mathrm{i}$ \\
\hline A18 & 25.33 & & & & & $\mathrm{f}$ & 5.44 & & & & & & & $\mathrm{~h}$ & i & 19.03 & & & & & & & $\mathrm{i}$ & 20.91 & & & & & & & i \\
\hline A19 & 23.49 & & & & $\mathrm{e}$ & $\mathrm{f}$ & 4.56 & & & $\mathrm{~d}$ & $\mathrm{e}$ & $\mathrm{f}$ & $\mathrm{g}$ & $\mathrm{h}$ & & 16.33 & & & & e & f $g$ & $h$ & $\mathrm{i}$ & 18.42 & & 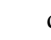 & $\mathrm{d}$ & e & f $g$ & g h & $\mathrm{i}$ \\
\hline A 20 & 23.04 & & & d & $\mathrm{e}$ & $\mathrm{f}$ & 4.95 & & & & & $\mathrm{f}$ & $\mathrm{g}$ & $\mathrm{h}$ & & 17.16 & & & & & f $g$ & $h$ & $\mathrm{i}$ & 18.70 & & & 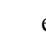 & e & $\mathrm{f} g$ & $\mathrm{~g} h$ & $\mathrm{i}$ \\
\hline A 21 & 22.46 & & & $\mathrm{~d}$ & $\mathrm{e}$ & $\mathrm{f}$ & 4.89 & & & & & $\mathrm{f}$ & $\mathrm{g}$ & $\mathrm{h}$ & & 17.44 & & & & & g & $h$ & $\mathrm{i}$ & 19.44 & & & & & f $g$ & $\mathrm{~g} h$ & $\mathrm{i}$ \\
\hline A22 & 22.26 & & & $\mathrm{~d}$ & $\mathrm{e}$ & $\mathrm{f}$ & 4.07 & & c & c d & $\mathrm{e}$ & $\mathrm{f}$ & & & & 15.48 & & & $\mathrm{~d}$ & $\mathrm{e}$ & f $g$ & $h$ & & 17.94 & & & $\mathrm{~d}$ & e & $\mathrm{f} g$ & $\mathrm{~g} \quad \mathrm{~h}$ & \\
\hline A23 & 20.06 & & $\mathrm{c}$ & d & & & 3.80 & & b c & $\mathrm{c} \quad \mathrm{d}$ & $\mathrm{e}$ & & & & & 14.10 & $\mathrm{~b}$ & $\mathrm{c}$ & $\mathrm{d}$ & $\mathrm{e}$ & & & & 15.77 & $\mathrm{~b}$ & c & $\mathrm{d}$ & & & & \\
\hline A24 & 24.32 & & & & $\mathrm{e}$ & $\mathrm{f}$ & 5.15 & & & & & & $\mathrm{~g}$ & $\mathrm{~h}$ & $\mathrm{i}$ & 18.21 & & & & & & $\mathrm{~h}$ & $\mathrm{i}$ & 20.88 & & & & & & & $\mathrm{i}$ \\
\hline A25 & 22.80 & & & $\mathrm{~d}$ & $\mathrm{e}$ & $\mathrm{f}$ & 4.75 & & & & $\mathrm{e}$ & $\mathrm{f}$ & $\mathrm{g}$ & $\mathrm{h}$ & & 16.92 & & & & & f $g$ & $h$ & $\mathrm{i}$ & 18.76 & & & 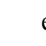 & e & $\mathrm{f} \quad \mathrm{g}$ & $\mathrm{g} \quad \mathrm{h}$ & $\mathrm{i}$ \\
\hline A26 & 22.95 & & & $\mathrm{~d}$ & $\mathrm{e}$ & $\mathrm{f}$ & 4.59 & & & & $\mathrm{e}$ & $\mathrm{f}$ & $\mathrm{g}$ & $\mathrm{h}$ & & 16.63 & & & & e & f $g$ & $h$ & $\mathrm{i}$ & 19.16 & & & & & $\mathrm{f} g$ & $\mathrm{~g} h$ & $\mathrm{i}$ \\
\hline A27 & 16.98 & $\mathrm{a} \quad \mathrm{b}$ & & & & & 3.50 & & b c & c d & & & & & & 11.86 & $\mathrm{~b}$ & & & & & & & 14.06 & $\mathrm{~b}$ & & & & & & \\
\hline A29 & 23.03 & & & $\mathrm{~d}$ & $\mathrm{e}$ & $\mathrm{f}$ & 5.41 & & & & & & & $\mathrm{~h}$ & & 17.42 & & & & & $\mathrm{~g}$ & $h$ & $\mathrm{i}$ & 19.75 & & & & & & $g \quad h$ & $\mathrm{i}$ \\
\hline A 30 & 23.28 & & & $\mathrm{~d}$ & $\mathrm{e}$ & $\mathrm{f}$ & 4.53 & & & $\mathrm{~d}$ & e & $\mathrm{f}$ & $\mathrm{g}$ & $\mathrm{h}$ & & 17.06 & & & & & f $g$ & $h$ & $\mathrm{i}$ & 19.03 & & & & & $\mathrm{f} g$ & $g \quad h$ & $\mathrm{i}$ \\
\hline A 31 & 21.81 & & & $\mathrm{~d}$ & $\mathrm{e}$ & & 4.22 & & & $\mathrm{~d}$ & e & $\mathrm{f}$ & $\mathrm{g}$ & & & 15.75 & & & $\mathrm{~d}$ & $\mathrm{e}$ & f $g$ & $\mathrm{~h}$ & & 18.42 & & & $\mathrm{~d}$ & e & $\mathrm{f} g$ & $g \quad h$ & $\mathrm{i}$ \\
\hline A 32 & 21.04 & & $\mathrm{c}$ & $\mathrm{d}$ & $\mathrm{e}$ & & 4.03 & & c & c d & e & $\mathrm{f}$ & & & & 14.37 & $\mathrm{~b}$ & $\mathrm{c}$ & $\mathrm{d}$ & e & $\mathrm{f}$ & & & 15.96 & $\mathrm{~b}$ & $\mathrm{c}$ & $\mathrm{d}$ & e & & & \\
\hline A33 & 23.34 & & & $\mathrm{~d}$ & $\mathrm{e}$ & $\mathrm{f}$ & 3.91 & & $b \quad c$ & c d & e & $\mathrm{f}$ & & & & 14.71 & & $\mathrm{c}$ & $\mathrm{d}$ & e & f $g$ & & & 17.61 & & & & & f $g$ & $g \quad h$ & \\
\hline A34 & 21.67 & & & $\mathrm{~d}$ & $\mathrm{e}$ & & 3.71 & & $b \quad c$ & c d & $\mathrm{e}$ & & & & & 14.02 & $\mathrm{~b}$ & $\mathrm{c}$ & $\mathrm{d}$ & e & & & & 16.60 & $\mathrm{~b}$ & c & d & e & $\mathrm{f}$ & & \\
\hline A35 & 22.84 & & & $\mathrm{~d}$ & $\mathrm{e}$ & $\mathrm{f}$ & 3.15 & $\mathrm{a}$ & b c c & c & & & & & & 13.05 & $\mathrm{~b}$ & $\mathrm{c}$ & $\mathrm{d}$ & & & & & 15.60 & & & & & & & \\
\hline A36 & 21.80 & & & $\mathrm{~d}$ & $\mathrm{e}$ & & 2.98 & $\mathrm{a}$ & $\mathrm{b}$ & & & & & & & 12.14 & $\mathrm{~b}$ & $\mathrm{c}$ & & & & & & 14.69 & $\mathrm{~b}$ & $\mathrm{c}$ & & & & & \\
\hline A37 & 15.54 & $\mathrm{a}$ & & & & & 2.66 & $\mathrm{a}$ & & & & & & & & 9.54 & & & & & & & & $11.02 \mathrm{a}$ & & & & & & & \\
\hline A39 & 21.15 & & $\mathrm{c}$ & $\mathrm{d}$ & $\mathrm{e}$ & & 3.93 & & b c c & $c \quad d$ & $\mathrm{e}$ & $\mathrm{f}$ & & & & 14.51 & & $\mathrm{c}$ & $\mathrm{d}$ & e & $\mathrm{f}$ & & & 16.96 & & & $\mathrm{~d}$ & e & $\mathrm{g}$ & & \\
\hline $\mathrm{A} 40$ & 18.54 & $\mathrm{~b}$ & $\mathrm{c}$ & & & & 4.52 & & & $\mathrm{~d}$ & $\mathrm{e}$ & $\mathrm{f}$ & $\mathrm{g}$ & $\mathrm{h}$ & & 14.57 & & $\mathrm{c}$ & $\mathrm{d}$ & e & $\mathrm{f}$ & & & 15.76 & $\mathrm{~b}$ & c & $\mathrm{d}$ & & & & \\
\hline A41 & 21.16 & & $\mathrm{c}$ & $\mathrm{d}$ & $\mathrm{e}$ & & 5.84 & & & & & & & & $\mathrm{i}$ & 17.70 & & & & & & $\mathrm{~h}$ & $\mathrm{i}$ & 20.04 & & & & & & $\mathrm{~h}$ & $\mathrm{i}$ \\
\hline Mean & 21.82 & & & & & & 4.29 & & & & & & & & & 15.35 & & & & & & & & 17.55 & & & & & & & \\
\hline
\end{tabular}

Means within a column followed by different letters are significantly different $(\mathrm{P}<0.05)$ according to the Student-Newman-Keuls multiple range test . 
Table S4. Continued.

\begin{tabular}{|c|c|c|c|c|c|c|c|c|c|c|c|c|c|c|c|c|c|c|c|c|c|c|}
\hline \multirow{2}{*}{$\frac{\text { Accession }}{\text { A16 }}$} & \multicolumn{6}{|c|}{$\begin{array}{l}\text { Crown leaf distance of the } \\
\text { maximum width point } \\
(\mathrm{cm} ; \mathrm{C} 15)\end{array}$} & \multicolumn{9}{|c|}{$\begin{array}{c}\text { Crown leaf apex angle } \\
\text { (degrees; C16) }\end{array}$} & \multicolumn{7}{|c|}{$\begin{array}{l}\text { Crown leaf petiole length } \\
\qquad(\mathrm{cm} ; \mathrm{C} 17)\end{array}$} \\
\hline & 8.13 & & & $\mathrm{c}$ & $\mathrm{d}$ & $\mathrm{e}$ & 63.99 & & & $\mathrm{c}$ & $\mathrm{d}$ & $\mathrm{e}$ & $\mathrm{f}$ & & & 7.18 & $\mathrm{a}$ & $\mathrm{b}$ & $\mathrm{c}$ & & & \\
\hline A17 & 8.51 & & & & & $\mathrm{e}$ & 77.47 & & & & & & $\mathrm{f}$ & $\mathrm{g}$ & $\mathrm{h}$ & 8.16 & & & $\mathrm{c}$ & $\mathrm{d}$ & $\mathrm{e}$ & \\
\hline A18 & 8.65 & & & & & e & 80.44 & & & & & & & $\mathrm{~g}$ & $\mathrm{~h}$ & 9.25 & & & & & $\mathrm{e}$ & $\mathrm{f}$ \\
\hline A19 & 7.73 & & & $\mathrm{c}$ & $\mathrm{d}$ & e & 64.60 & & & $\mathrm{c}$ & $\mathrm{d}$ & $\mathrm{e}$ & $\mathrm{f}$ & & & 8.53 & & & $\mathrm{c}$ & $\mathrm{d}$ & $\mathrm{e}$ & $\mathrm{f}$ \\
\hline A20 & 7.53 & & & $\mathrm{c}$ & $\mathrm{d}$ & e & 73.99 & & & & & e & $\mathrm{f}$ & g & $\mathrm{h}$ & 8.83 & & & $\mathrm{c}$ & $\mathrm{d}$ & $\mathrm{e}$ & $\mathrm{f}$ \\
\hline A21 & 8.80 & & & & & e & 69.54 & & & & $\mathrm{~d}$ & e & $\mathrm{f}$ & g & $\mathrm{h}$ & 8.45 & & & $\mathrm{c}$ & $\mathrm{d}$ & $\mathrm{e}$ & $\mathrm{f}$ \\
\hline A22 & 8.29 & & & $\mathrm{c}$ & $\mathrm{d}$ & $\mathrm{e}$ & 69.85 & & & & $\mathrm{~d}$ & $\mathrm{e}$ & $\mathrm{f}$ & $\mathrm{g}$ & $\mathrm{h}$ & 8.74 & & & $\mathrm{c}$ & $\mathrm{d}$ & $\mathrm{e}$ & $\mathrm{f}$ \\
\hline A23 & 7.12 & & $\mathrm{~b}$ & $\mathrm{c}$ & $\mathrm{d}$ & e & 59.73 & & $\mathrm{~b}$ & $\mathrm{c}$ & $\mathrm{d}$ & $\mathrm{e}$ & & & & 7.86 & & $\mathrm{~b}$ & $\mathrm{c}$ & $\mathrm{d}$ & $\mathrm{e}$ & \\
\hline A24 & 8.67 & & & & & e & 82.82 & & & & & & & & $\mathrm{~h}$ & 8.65 & & & $\mathrm{c}$ & $\mathrm{d}$ & $\mathrm{e}$ & $\mathrm{f}$ \\
\hline A25 & 7.67 & & & $\mathrm{c}$ & $\mathrm{d}$ & e & 77.75 & & & & & & $\mathrm{f}$ & $\mathrm{g}$ & $\mathrm{h}$ & 7.92 & & $\mathrm{~b}$ & $\mathrm{c}$ & $\mathrm{d}$ & e & \\
\hline A26 & 8.06 & & & $\mathrm{c}$ & $\mathrm{d}$ & $\mathrm{e}$ & 75.46 & & & & & & $\mathrm{f}$ & $\mathrm{g}$ & $\mathrm{h}$ & 8.10 & & & $\mathrm{c}$ & $\mathrm{d}$ & $\mathrm{e}$ & \\
\hline $\mathrm{A} 27$ & 5.74 & $\mathrm{a}$ & $\mathrm{b}$ & & & & 53.68 & & $\mathrm{~b}$ & $\mathrm{c}$ & & & & & & 9.44 & & & & & e & $\mathrm{f}$ \\
\hline A29 & 8.02 & & & $\mathrm{c}$ & $\mathrm{d}$ & e & 69.06 & & & & $\mathrm{~d}$ & $\mathrm{e}$ & $\mathrm{f}$ & $\mathrm{g}$ & $\mathrm{h}$ & 9.05 & & & & $\mathrm{~d}$ & $\mathrm{e}$ & $\mathrm{f}$ \\
\hline A 30 & 8.15 & & & $\mathrm{c}$ & d & $\mathrm{e}$ & 77.21 & & & & & & $\mathrm{f}$ & $\mathrm{g}$ & $\mathrm{h}$ & 8.13 & & & $\mathrm{c}$ & $\mathrm{d}$ & $\mathrm{e}$ & \\
\hline A31 & 7.85 & & & $\mathrm{c}$ & d & e & 71.97 & & & & & $\mathrm{e}$ & $\mathrm{f}$ & $\mathrm{g}$ & $\mathrm{h}$ & 8.76 & & & $\mathrm{c}$ & $\mathrm{d}$ & e & $\mathrm{f}$ \\
\hline A32 & 6.98 & & $\mathrm{~b}$ & $\mathrm{c}$ & $\mathrm{d}$ & e & 55.28 & & $\mathrm{~b}$ & $\mathrm{c}$ & $\mathrm{d}$ & & & & & 7.44 & & $\mathrm{~b}$ & $\mathrm{c}$ & $\mathrm{d}$ & & \\
\hline A33 & 7.63 & & & $\mathrm{c}$ & $\mathrm{d}$ & e & 56.32 & & $\mathrm{~b}$ & $\mathrm{c}$ & $\mathrm{d}$ & & & & & 8.34 & & & $\mathrm{c}$ & $\mathrm{d}$ & $\mathrm{e}$ & $\mathrm{f}$ \\
\hline A34 & 7.17 & & $\mathrm{~b}$ & $\mathrm{c}$ & $\mathrm{d}$ & e & 64.67 & & & $\mathrm{c}$ & $\mathrm{d}$ & $\mathrm{e}$ & $\mathrm{f}$ & & & 7.75 & & b & $\mathrm{c}$ & $\mathrm{d}$ & $\mathrm{e}$ & \\
\hline A35 & 6.57 & & $\mathrm{~b}$ & c & & & 49.72 & $\mathrm{a}$ & $\mathrm{b}$ & & & & & & & 7.26 & $\mathrm{a}$ & $\mathrm{b}$ & $\mathrm{c}$ & & & \\
\hline A36 & 7.02 & & $\mathrm{~b}$ & $\mathrm{c}$ & $\mathrm{d}$ & $\mathrm{e}$ & 40.95 & $\mathrm{a}$ & & & & & & & & 8.52 & & & & $\mathrm{~d}$ & $\mathrm{e}$ & $\mathrm{f}$ \\
\hline A37 & 5.04 & $\mathrm{a}$ & & & & & 56.45 & & $\mathrm{~b}$ & $\mathrm{c}$ & & & & & & 6.02 & $\mathrm{a}$ & & & & & \\
\hline A39 & 6.66 & & $\mathrm{~b}$ & $\mathrm{c}$ & $\mathrm{d}$ & & 64.26 & & & $\mathrm{c}$ & $\mathrm{d}$ & e & $\mathrm{f}$ & & & 7.29 & $\mathrm{a}$ & $\mathrm{b}$ & $\mathrm{c}$ & & & \\
\hline A40 & 6.48 & & $\mathrm{~b}$ & $\mathrm{c}$ & & & 65.89 & & & $\mathrm{c}$ & $\mathrm{d}$ & $\mathrm{e}$ & $\mathrm{f}$ & $\mathrm{g}$ & & 6.56 & $\mathrm{a}$ & $\mathrm{b}$ & & & & \\
\hline A41 & 8.41 & & & & $\mathrm{~d}$ & $\mathrm{e}$ & 83.82 & & & & & & & & $\mathrm{~h}$ & 9.88 & & & & & & $\mathrm{f}$ \\
\hline Mean & 7.54 & & & & & & 66.87 & & & & & & & & & 8.17 & & & & & & \\
\hline
\end{tabular}

Means within a column followed by different letters are significantly different $(\mathrm{P}<0.05)$ according to the StudentNewman-Keuls multiple range test. 


\section{Inflorescence and flower}

Table S5. Means and multiple comparison among mean differences for the 24 accessions for the inflorescence and flower traits studied.

\begin{tabular}{|c|c|c|c|c|c|c|c|c|c|c|c|c|c|c|c|c|c|c|c|c|c|c|}
\hline \multirow{2}{*}{$\begin{array}{c}\text { Accession } \\
\text { A16 }\end{array}$} & \multicolumn{2}{|l|}{$\begin{array}{c}\text { Inflorescence } \\
\text { length } \\
(\mathrm{cm} ; \mathrm{C} 18)\end{array}$} & \multicolumn{3}{|c|}{$\begin{array}{l}\text { Inflorescence } \\
\text { peduncle } \\
\text { length } \\
(\mathrm{cm} ; \mathrm{C} 19)\end{array}$} & \multicolumn{4}{|c|}{$\begin{array}{c}\text { Inflorescence } \\
\text { rachis } \\
\text { Internode } \\
\text { length } \\
(\mathrm{cm} ; \mathrm{C} 20)\end{array}$} & \multicolumn{2}{|c|}{$\begin{array}{c}\text { Petal } \\
\text { length } \\
(\mathrm{cm} ; \mathrm{C} 21)\end{array}$} & \multicolumn{2}{|c|}{$\begin{array}{c}\text { Petal } \\
\text { width } \\
(\mathrm{cm} ; \mathrm{C} 22)\end{array}$} & \multicolumn{2}{|c|}{$\begin{array}{c}\text { Corolla } \\
\text { diameter } \\
(\mathrm{cm} ; \mathrm{C} 23)\end{array}$} & \multicolumn{3}{|c|}{$\begin{array}{l}\text { Anther } \\
\text { length } \\
(\mathrm{cm} ; \mathrm{C} 24)\end{array}$} & \multicolumn{4}{|c|}{$\begin{array}{l}\text { Style length } \\
(\mathrm{cm} ; \mathrm{C} 25)\end{array}$} \\
\hline & 7.67 & b & 3.56 & b & c & 2.18 & $\mathrm{a}$ & $\mathrm{b}$ & $\mathrm{c}$ & 1.16 & $\mathrm{a}$ & 0.49 & $\mathrm{a}$ & 2.32 & $\mathrm{a}$ & 0.63 & & b & 0.61 & $\mathrm{a}$ & b & $\mathrm{c}$ \\
\hline A17 & 9.15 & b & 4.36 & $b$ & c & 2.35 & & b & $\mathrm{c}$ & 1.17 & $\mathrm{a}$ & 0.48 & $\mathrm{a}$ & 2.34 & $\mathrm{a}$ & 0.57 & a & b & 0.62 & & b & $\mathrm{c}$ \\
\hline A18 & 7.87 & b & 3.84 & b & $\mathrm{c}$ & 2.20 & $\mathrm{a}$ & b & $\mathrm{c}$ & 1.07 & $\mathrm{a}$ & 0.52 & $\mathrm{a}$ & 2.14 & $\mathrm{a}$ & 0.55 & $\mathrm{a}$ & b & 0.57 & a & b & $\mathrm{c}$ \\
\hline A19 & 8.25 & $\mathrm{~b}$ & 3.64 & b & c & 2.11 & $\mathrm{a}$ & $\mathrm{b}$ & $c$ & 1.22 & $\mathrm{a}$ & 0.42 & $\mathrm{a}$ & 2.43 & $\mathrm{a}$ & 0.60 & $\mathrm{a}$ & $\mathrm{b}$ & 0.58 & $\mathrm{a}$ & $\mathrm{b}$ & $\mathrm{c}$ \\
\hline A20 & 7.49 & b & 2.76 & b & & 2.12 & $\mathrm{a}$ & b & $\mathrm{c}$ & 1.25 & $\mathrm{a}$ & 0.56 & $\mathrm{a}$ & 2.57 & $\mathrm{a}$ & 0.55 & $\mathrm{a}$ & b & 0.57 & $\mathrm{a}$ & b & $\mathrm{c}$ \\
\hline A21 & 7.29 & b & 3.64 & $\mathrm{~b}$ & $\mathrm{c}$ & 2.28 & $\mathrm{a}$ & b & $\mathrm{c}$ & 1.05 & $\mathrm{a}$ & 0.50 & a & 2.10 & a & 0.61 & $\mathrm{a}$ & b & 0.54 & $\mathrm{a}$ & $\mathrm{b}$ & \\
\hline A22 & 8.13 & $b$ & 3.12 & b & $\mathrm{c}$ & 2.77 & & & $\mathrm{c}$ & 1.23 & $\mathrm{a}$ & 0.44 & $\mathrm{a}$ & 2.47 & $\mathrm{a}$ & 0.58 & $\mathrm{a}$ & b & 0.63 & & $\mathrm{~b}$ & $\mathrm{c}$ \\
\hline A23 & 8.65 & $\mathrm{~b}$ & 3.57 & $\mathrm{~b}$ & $\mathrm{c}$ & 2.59 & & $\mathrm{~b}$ & $\mathrm{c}$ & 1.19 & $\mathrm{a}$ & 0.47 & $\mathrm{a}$ & 2.38 & $\mathrm{a}$ & 0.55 & $\mathrm{a}$ & $\mathrm{b}$ & 0.58 & $\mathrm{a}$ & $\mathrm{b}$ & $\mathrm{c}$ \\
\hline A24 & 8.70 & b & 3.67 & b & $c$ & 2.38 & & b & $\mathrm{c}$ & 1.23 & $\mathrm{a}$ & 0.47 & $\mathrm{a}$ & 2.47 & $\mathrm{a}$ & 0.56 & $\mathrm{a}$ & b & 0.58 & $\mathrm{a}$ & b & $\mathrm{c}$ \\
\hline A25 & 8.40 & b & 3.31 & b & $\mathrm{c}$ & 2.33 & & b & c & 1.30 & $\mathrm{a}$ & 0.53 & $\mathrm{a}$ & 2.59 & $\mathrm{a}$ & 0.60 & $\mathrm{a}$ & b & 0.58 & $\mathrm{a}$ & b & $\mathrm{c}$ \\
\hline A26 & 8.08 & b & 3.46 & b & c & 2.01 & $\mathrm{a}$ & b & & 1.22 & $\mathrm{a}$ & 0.53 & a & 2.45 & a & 0.57 & $\mathrm{a}$ & b & 0.53 & $\mathrm{a}$ & $\mathrm{b}$ & \\
\hline A27 & 7.73 & $\mathrm{~b}$ & 3.88 & $\mathrm{~b}$ & $\mathrm{c}$ & 2.18 & $\mathrm{a}$ & $\mathrm{b}$ & $c$ & 1.18 & $\mathrm{a}$ & 0.51 & $\mathrm{a}$ & 2.36 & $\mathrm{a}$ & 0.59 & $\mathrm{a}$ & b & 0.57 & $\mathrm{a}$ & $\mathrm{b}$ & $\mathrm{c}$ \\
\hline A29 & 9.56 & b & 4.93 & & $\mathrm{c}$ & 2.33 & & $\mathrm{~b}$ & $\mathrm{c}$ & 1.25 & $\mathrm{a}$ & 0.53 & $\mathrm{a}$ & 2.60 & $\mathrm{a}$ & 0.59 & $\mathrm{a}$ & b & 0.60 & $\mathrm{a}$ & b & $\mathrm{c}$ \\
\hline A 30 & 8.17 & b & 3.23 & b & $\mathrm{c}$ & 2.32 & & b & $\mathrm{c}$ & 1.32 & $\mathrm{a}$ & 0.52 & $\mathrm{a}$ & 2.64 & $\mathrm{a}$ & 0.58 & $\mathrm{a}$ & b & 0.60 & $\mathrm{a}$ & b & $\mathrm{c}$ \\
\hline A31 & 8.40 & $\mathrm{~b}$ & 3.78 & $b$ & c & 2.46 & & $\mathrm{~b}$ & c & 1.26 & $\mathrm{a}$ & 0.52 & $\mathrm{a}$ & 2.52 & $\mathrm{a}$ & 0.59 & $\mathrm{a}$ & b & 0.64 & & $\mathrm{~b}$ & $\mathrm{c}$ \\
\hline A 32 & 7.92 & $\mathrm{~b}$ & 3.60 & $\mathrm{~b}$ & $\mathrm{c}$ & 2.21 & $\mathrm{a}$ & $\mathrm{b}$ & $\mathrm{c}$ & 1.11 & $\mathrm{a}$ & 0.47 & $\mathrm{a}$ & 2.21 & $\mathrm{a}$ & 0.57 & $\mathrm{a}$ & $\mathrm{b}$ & 0.57 & $\mathrm{a}$ & $\mathrm{b}$ & $\mathrm{c}$ \\
\hline A33 & 8.23 & $\mathrm{~b}$ & 3.99 & $\mathrm{~b}$ & $\mathrm{c}$ & 2.03 & $\mathrm{a}$ & $\mathrm{b}$ & & 1.13 & $\mathrm{a}$ & 0.48 & $\mathrm{a}$ & 2.27 & $\mathrm{a}$ & 0.66 & & $\mathrm{~b}$ & 0.60 & $\mathrm{a}$ & $\mathrm{b}$ & $\mathrm{c}$ \\
\hline A34 & 8.98 & $b$ & 4.47 & b & $\mathrm{c}$ & 2.36 & & b & $\mathrm{c}$ & 1.23 & $\mathrm{a}$ & 0.45 & $\mathrm{a}$ & 2.46 & $\mathrm{a}$ & 0.56 & $\mathrm{a}$ & $b$ & 0.59 & $\mathrm{a}$ & $\mathrm{b}$ & $\mathrm{c}$ \\
\hline A35 & 7.44 & b & 3.32 & b & $\mathrm{c}$ & 2.13 & $\mathrm{a}$ & b & $\mathrm{c}$ & 1.24 & $\mathrm{a}$ & 0.44 & $\mathrm{a}$ & 2.49 & $\mathrm{a}$ & 0.52 & $\mathrm{a}$ & b & 0.59 & $\mathrm{a}$ & $\mathrm{b}$ & $\mathrm{c}$ \\
\hline A36 & 8.18 & $\mathrm{~b}$ & 3.33 & $b$ & c & 2.16 & $\mathrm{a}$ & $\mathrm{b}$ & $\mathrm{c}$ & 1.16 & $\mathrm{a}$ & 0.45 & $\mathrm{a}$ & 2.32 & $\mathrm{a}$ & 0.51 & $\mathrm{a}$ & $\mathrm{b}$ & 0.69 & & & $\mathrm{c}$ \\
\hline A37 & 8.33 & $\mathrm{~b}$ & 3.42 & $\mathrm{~b}$ & c & 2.16 & $\mathrm{a}$ & $\mathrm{b}$ & $\mathrm{c}$ & 1.12 & $\mathrm{a}$ & 0.44 & $\mathrm{a}$ & 2.23 & $\mathrm{a}$ & 0.55 & $\mathrm{a}$ & $\mathrm{b}$ & 0.62 & & $\mathrm{~b}$ & $\mathrm{c}$ \\
\hline A39 & 7.89 & $\mathrm{~b}$ & 3.14 & $\mathrm{~b}$ & $\mathrm{c}$ & 1.94 & $\mathrm{a}$ & $\mathrm{b}$ & & 1.22 & $\mathrm{a}$ & 0.47 & $\mathrm{a}$ & 2.44 & $\mathrm{a}$ & 0.58 & $\mathrm{a}$ & $\mathrm{b}$ & 0.59 & $\mathrm{a}$ & $\mathrm{b}$ & $\mathrm{c}$ \\
\hline A40 & 7.94 & b & 3.42 & b & $\mathrm{c}$ & 2.32 & & $\mathrm{~b}$ & 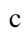 & 1.27 & $\mathrm{a}$ & 0.48 & $\mathrm{a}$ & 2.54 & $\mathrm{a}$ & 0.58 & $\mathrm{a}$ & b & 0.61 & $\mathrm{a}$ & $\mathrm{b}$ & $\mathrm{c}$ \\
\hline A41 & 4.73 & & 1.63 & $\mathrm{a}$ & & 1.61 & $\mathrm{a}$ & & & 1.00 & $\mathrm{a}$ & 0.45 & $\mathrm{a}$ & 2.00 & $\mathrm{a}$ & 0.48 & $\mathrm{a}$ & & 0.48 & $\mathrm{a}$ & & \\
\hline Mean & 8.05 & & 3.54 & & & 2.23 & & & & 1.19 & & 0.48 & & 2.39 & & 0.57 & & & 0.59 & & & \\
\hline
\end{tabular}

Means within a column followed by different letters are significantly different $(\mathrm{P}<0.05)$ according to the Student-Newman-Keuls multiple range test. 


\section{Infructescence and fruit}

Table S6. Means and multiple comparison among mean differences for the 24 accessions for the infructescence and fruit traits studied.

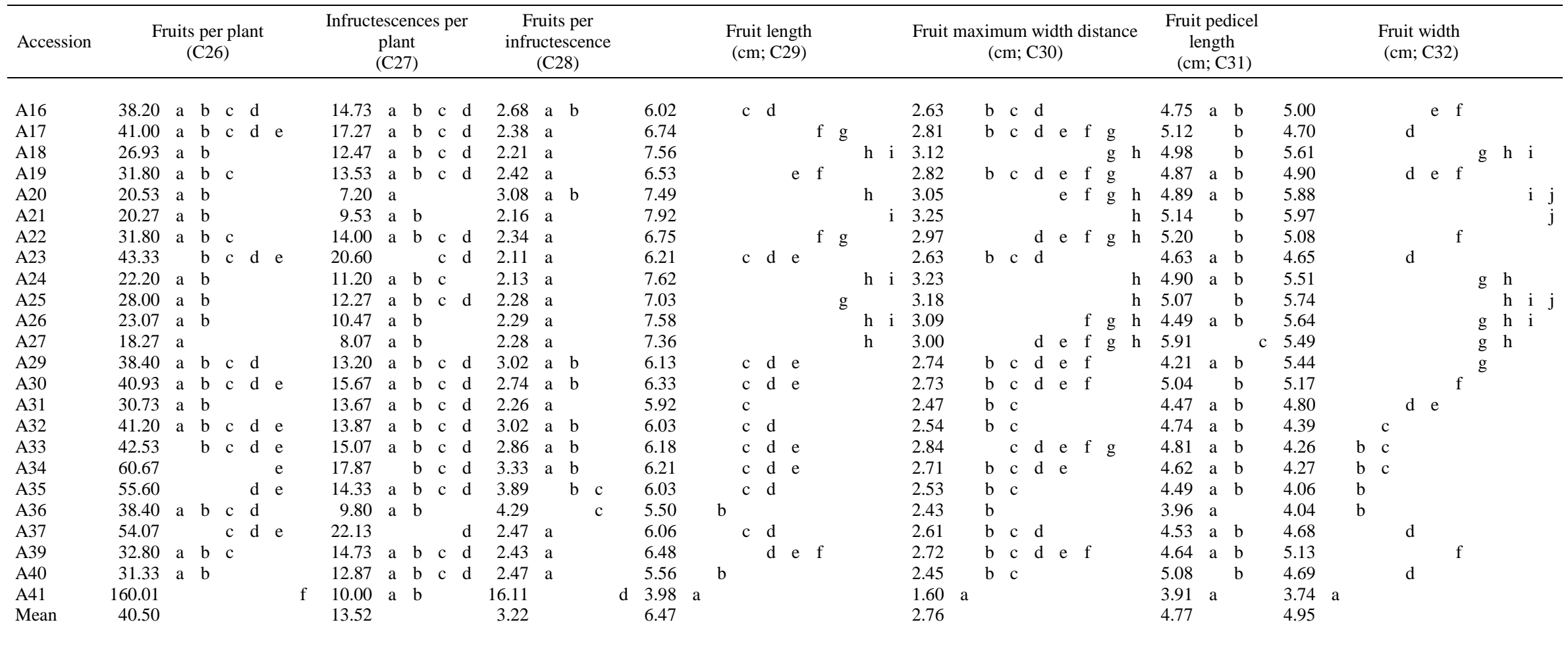

Means within a column followed by different letters are significantly different $(\mathrm{P}<0.05)$ according to the Student-Newman-Keuls multiple range test. 
Table S6. Continued.

\begin{tabular}{|c|c|c|c|c|c|c|c|c|c|c|c|c|c|c|c|c|c|c|c|c|c|c|c|c|c|c|c|c|}
\hline Accession & & $\begin{array}{l}\text { ruit a } \\
\text { (degr }\end{array}$ & $\begin{array}{l}\text { apex } \\
\text { rees; }\end{array}$ & $\begin{array}{l}\text { ex an } \\
\text { s; } 3\end{array}$ & & & & & & & $\begin{array}{l}\text { uit wei } \\
\mathrm{g} ; \mathrm{C} 3\end{array}$ & $\begin{array}{l}\text { eight } \\
\text { 34) }\end{array}$ & & & & & & ruit & & $\begin{array}{l}\text { igth } \\
\text { (C) }\end{array}$ & /Wic & & rati & & & & $\begin{array}{r}\text { Fruit length/m } \\
\text { width distan } \\
\text { (C36) }\end{array}$ & $\begin{array}{l}\text { aximum } \\
\text { ce ratio }\end{array}$ \\
\hline A16 & 130.68 & & & & $\mathrm{e}$ & e & & & 83.47 & & c d & $\mathrm{d} e$ & & & & 1.20 & & b & $\mathrm{c}$ & d & & & & & & & 2.30 & $\mathrm{a}$ \\
\hline A17 & 122.46 & $\mathrm{a}$ & b c & c d & & & & & 78.36 & & c & & & & & 1.43 & & & & & & & & & $\mathrm{i} j$ & $\begin{array}{ll}j & k\end{array}$ & 2.40 & a \\
\hline A18 & 128.59 & & & c d & e & e & & & 130.46 & & & & & $\mathrm{~g}$ & $\mathrm{~h}$ & 1.35 & & & & & & & $\mathrm{~g}$ & $\mathrm{~h}$ & i & & 2.42 & $\mathrm{a}$ \\
\hline A19 & 129.12 & & & d & e & e & & & 86.29 & & $c \quad d$ & $\mathrm{~d} e$ & $\mathrm{f}$ & & & 1.33 & & & & & $\mathrm{e}$ & f & $\mathrm{g}$ & $\mathrm{h}$ & i & & 2.31 & $\mathrm{a}$ \\
\hline A20 & 129.03 & & & d & e & 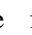 & & & 139.24 & & & & & & $\mathrm{~h}$ & 1.28 & & & $\mathrm{c}$ & d & $\mathrm{e}$ & f & $\mathrm{g}$ & $\mathrm{h}$ & & & 2.46 & $\mathrm{a}$ \\
\hline A21 & 130.34 & & & & e & 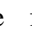 & & & 154.18 & & & & & & $\mathrm{i}$ & 1.33 & & & & & e & f & $\mathrm{g}$ & $\mathrm{h}$ & $\mathrm{i}$ & & 2.44 & $\mathrm{a}$ \\
\hline A22 & 134.34 & & & & & & & & 98.18 & & & $\mathrm{e}$ & $\mathrm{f}$ & & & 1.33 & & & & & $\mathrm{e}$ & f & $\mathrm{g}$ & $\mathrm{h}$ & i & & 2.28 & a \\
\hline A23 & 127.99 & 1 & b c & c d & e & e & & & 75.72 & & $\mathrm{c}$ & & & & & 1.34 & & & & & & $\mathrm{f}$ & g & $\mathrm{h}$ & i & & 2.36 & $\mathrm{a}$ \\
\hline A24 & 129.64 & & & d & e & e & & & 123.37 & & & & & $\mathrm{~g}$ & & 1.38 & & & & & & & & $\mathrm{~h}$ & $\mathrm{i} j$ & & 2.36 & $\mathrm{a}$ \\
\hline A25 & 134.69 & & & & & & & & 132.36 & & & & & $\mathrm{~g}$ & $\mathrm{~h}$ & 1.23 & & & c & d & $\mathrm{e}$ & & & & & & 2.22 & a \\
\hline A26 & 125.36 & $\mathrm{a}$ & b c & c d & e & e & & & 131.56 & & & & & $\mathrm{~g}$ & $\mathrm{~h}$ & 1.35 & & & & & & & g & $\mathrm{h}$ & i & & 2.45 & $\mathrm{a}$ \\
\hline A27 & 127.85 & 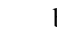 & b c & $\mathrm{c} \quad \mathrm{d}$ & e & 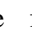 & & & 125.49 & & & & & $\mathrm{~g}$ & $\mathrm{~h}$ & 1.34 & & & & & & f & $\mathrm{g}$ & $\mathrm{h}$ & $\mathrm{i}$ & & 2.45 & $\mathrm{a}$ \\
\hline A29 & 132.19 & & & & & & & & 96.39 & & & $\mathrm{e}$ & $\mathrm{f}$ & & & 1.13 & $\mathrm{a}$ & b & & & & & & & & & 2.23 & a \\
\hline A30 & 134.32 & & & & & & & & 96.75 & & & $\mathrm{e}$ & $\mathrm{f}$ & & & 1.22 & & & $\mathrm{c}$ & d & $\mathrm{e}$ & & & & & & 2.32 & $\mathrm{a}$ \\
\hline A31 & 129.36 & & & d & e & e & & & 81.27 & & $\mathrm{c} \quad \mathrm{d}$ & & & & & 1.23 & & s & $\mathrm{c}$ & d & $\mathrm{e}$ & & & & & & 2.40 & $\mathrm{a}$ \\
\hline A32 & 121.60 & $\mathrm{a}$ & b & & & & & & 63.19 & $\mathrm{~b}$ & & & & & & 1.37 & & & & & & & g & $\mathrm{h}$ & $\mathrm{i} j$ & & 2.37 & $\mathrm{a}$ \\
\hline A33 & 120.20 & $\mathrm{a}$ & & & & & & & 60.96 & $\mathrm{~b}$ & & & & & & 1.45 & & & & & & & & & & $\mathrm{j} \quad \mathrm{k}$ & 2.20 & a \\
\hline A34 & 118.79 & $\mathrm{a}$ & & & & & & & 61.39 & $\mathrm{~b}$ & & & & & & 1.46 & & & & & & & & & & $\mathrm{j} \quad \mathrm{k}$ & 2.30 & $\mathrm{a}$ \\
\hline A35 & 119.22 & $\mathrm{a}$ & & & & & & & 54.19 & $\mathrm{~b}$ & & & & & & 1.49 & & & & & & & & & & $\mathrm{k}$ & 2.39 & $\mathrm{a}$ \\
\hline A36 & 121.93 & $\mathrm{a} \quad 1$ & b c & $\mathrm{c}$ & & & & & 50.69 & $\mathrm{~b}$ & & & & & & 1.36 & & & & & & & $\mathrm{~g}$ & $\mathrm{~h}$ & $\mathrm{i}$ & & 2.26 & a \\
\hline A37 & 132.67 & & & & & & & & 75.84 & & $\mathrm{c}$ & & & & & 1.30 & & & & d & $\mathrm{e}$ & f & g & $\mathrm{h}$ & & & 2.32 & $\mathrm{a}$ \\
\hline A39 & 132.78 & & & & & & & & 100.20 & & & & $\mathrm{f}$ & & & 1.26 & & & c & d & e & f & $\mathrm{g}$ & & & & 2.38 & $\mathrm{a}$ \\
\hline A40 & 131.42 & & & & & & & & 93.50 & & & $d e$ & $\mathrm{f}$ & & & 1.18 & & $\mathrm{~b}$ & $\mathrm{c}$ & & & & & & & & 2.27 & $\mathrm{a}$ \\
\hline A41 & 123.41 & $\mathrm{a}$ & b c & c d & e & & & & 30.51 & & & & & & & 1.06 & $\mathrm{a}$ & & & & & & & & & & 2.50 & $\mathrm{a}$ \\
\hline Mean & 127.83 & & & & & & & & 92.65 & & & & & & & 1.31 & & & & & & & & & & & 2.35 & \\
\hline
\end{tabular}

Means within a column followed by different letters are significantly different $(\mathrm{P}<0.05)$ according to the Student-Newman-Keuls multiple range test.

\section{Seed}

Table S7. Means and multiple comparison among mean differences for the 24 accessions for the seed traits studied.

\begin{tabular}{|c|c|c|c|c|c|c|c|c|c|c|c|c|c|c|c|c|c|}
\hline \multirow{2}{*}{$\frac{\text { Accession }}{\text { A16 }}$} & \multicolumn{5}{|c|}{$\begin{array}{l}\text { Seed length } \\
(\mathrm{mm} ; \mathrm{C} 37)\end{array}$} & \multicolumn{7}{|c|}{$\begin{array}{l}\text { Seed width } \\
(\mathrm{mm} ; \mathrm{C} 38)\end{array}$} & \multicolumn{5}{|c|}{$\begin{array}{l}\text { Seeds per fruit } \\
\text { (C39) }\end{array}$} \\
\hline & 4.00 & $\mathrm{~b}$ & $\mathrm{c}$ & d & $\mathrm{e}$ & 0.32 & & & & e & $\mathrm{f}$ & $\mathrm{g}$ & 239.80 & $\mathrm{c}$ & $\mathrm{d}$ & & \\
\hline A17 & 4.10 & & & d & $\mathrm{e}$ & 0.34 & & & & & & $\mathrm{~g}$ & 168.21 & $\mathrm{~b}$ & & & \\
\hline A18 & 3.90 & $\mathrm{~b}$ & $\mathrm{c}$ & $\mathrm{d}$ & $\mathrm{e}$ & 0.31 & $\mathrm{~b}$ & c & d & e & f & & 312.75 & & & $\mathrm{e}$ & f $g$ \\
\hline A19 & 3.80 & b & $\mathrm{c}$ & d & & 0.31 & & c & d & $\mathrm{e}$ & f & g & 282.80 & & $\mathrm{~d}$ & e & f \\
\hline A20 & 0.39 & b & c & d & & 3.20 & & c & $\mathrm{d}$ & $\mathrm{e}$ & f & $\mathrm{g}$ & 352.60 & & & $\mathrm{e}$ & $\mathrm{f}$ \\
\hline
\end{tabular}




\begin{tabular}{|c|c|c|c|c|c|c|c|c|c|c|c|c|c|c|c|c|c|c|c|c|}
\hline A21 & 4.00 & & & $\mathrm{c}$ & $\mathrm{d}$ & $\mathrm{e}$ & 3.20 & & & & d & $\mathrm{e}$ & f & $\mathrm{g}$ & 382.15 & & & & & $\mathrm{~g}$ \\
\hline A22 & 4.00 & & $\mathrm{~b}$ & $\mathrm{c}$ & $\mathrm{d}$ & $\mathrm{e}$ & 3.20 & & & & & $\mathrm{e}$ & f & g & 267.10 & & & $\mathrm{~d} \quad \mathrm{e}$ & & \\
\hline A23 & 3.70 & $\mathrm{a}$ & $\mathrm{b}$ & $\mathrm{c}$ & & & 3.00 & & $\mathrm{~b}$ & c & d & $\mathrm{e}$ & & & 268.71 & & $d$ & d e & & \\
\hline A24 & 3.70 & a & $\mathrm{b}$ & c & & & 3.00 & $\mathrm{a}$ & $\mathrm{b}$ & c & d & & & & 369.45 & & & & $\mathrm{f}$ & $\mathrm{g}$ \\
\hline A25 & 3.90 & & $\mathrm{~b}$ & $\mathrm{c}$ & $\mathrm{d}$ & $\mathrm{e}$ & 3.10 & & & c & d & $\mathrm{e}$ & f & g & 350.60 & & & $\mathrm{e}$ & $\mathrm{f}$ & $\mathrm{g}$ \\
\hline A26 & 3.80 & & $\mathrm{~b}$ & $\mathrm{c}$ & d & & 3.20 & & & c & d & $\mathrm{e}$ & f & $\mathrm{g}$ & 333.63 & & & $\mathrm{e}$ & $\mathrm{f}$ & $\mathrm{g}$ \\
\hline A27 & 3.70 & $\mathrm{a}$ & $\mathrm{b}$ & $\mathrm{c}$ & & & 3.10 & & $\mathrm{~b}$ & c & $\mathrm{d}$ & $\mathrm{e}$ & $\mathrm{f}$ & & 359.00 & & & $\mathrm{e}$ & $\mathrm{f}$ & $\mathrm{g}$ \\
\hline A29 & 3.70 & $\mathrm{a}$ & $\mathrm{b}$ & c & & & 3.10 & & $\mathrm{~b}$ & c & d & $\mathrm{e}$ & f & & 272.77 & & $\mathrm{~d}$ & $d e$ & & \\
\hline A30 & 3.80 & & $\mathrm{~b}$ & $\mathrm{c}$ & d & & 3.10 & & & c & $d$ & $\mathrm{e}$ & f & g & 244.11 & & $\mathrm{c} \quad \mathrm{d}$ & $d$ & & \\
\hline A31 & 4.00 & & $\mathrm{~b}$ & $\mathrm{c}$ & $\mathrm{d}$ & $\mathrm{e}$ & 3.40 & & & & & & & $\mathrm{~g}$ & 130.11 & $\mathrm{~b}$ & & & & \\
\hline A32 & 3.90 & & $\mathrm{~b}$ & $\mathrm{c}$ & d & & 3.30 & & & & & $\mathrm{e}$ & $\mathrm{f}$ & $\mathrm{g}$ & 130.16 & $\mathrm{~b}$ & & & & \\
\hline A33 & 3.90 & & $\mathrm{~b}$ & c & $\mathrm{d}$ & $\mathrm{e}$ & 3.30 & & & & & & $\mathrm{f}$ & $\mathrm{g}$ & 124.93 & b & & & & \\
\hline A34 & 3.90 & & $\mathrm{~b}$ & $\mathrm{c}$ & d & & 3.30 & & & & & $\mathrm{e}$ & f & $\mathrm{g}$ & 124.47 & $\mathrm{~b}$ & & & & \\
\hline A35 & 3.60 & $\mathrm{a}$ & $\mathrm{b}$ & & & & 3.00 & & $\mathrm{~b}$ & c & $\mathrm{d}$ & $\mathrm{e}$ & & & 186.07 & $\mathrm{~b} \quad \mathrm{c}$ & $\mathrm{c}$ & & & \\
\hline A36 & 3.50 & $\mathrm{a}$ & & & & & 2.80 & $\mathrm{a}$ & & & & & & & 151.88 & $\mathrm{~b}$ & & & & \\
\hline A37 & 3.50 & a & & & & & 2.90 & $\mathrm{a}$ & $\mathrm{b}$ & & & & & & 317.04 & & d & $\mathrm{e}$ & $\mathrm{f}$ & $\mathrm{g}$ \\
\hline A39 & 3.90 & & $\mathrm{~b}$ & $\mathrm{c}$ & d & & 3.20 & & & c & d & $\mathrm{e}$ & $\mathrm{f}$ & $\mathrm{g}$ & 306.88 & & $\mathrm{~d}$ & $\mathrm{e}$ & $\mathrm{f}$ & $\mathrm{g}$ \\
\hline A40 & 3.60 & $\mathrm{a}$ & $\mathrm{b}$ & & & & 2.90 & $\mathrm{a}$ & $\mathrm{b}$ & $\mathrm{c}$ & & & & & 306.89 & & d & $\mathrm{e}$ & $\mathrm{f}$ & $\mathrm{g}$ \\
\hline $\begin{array}{l}\text { A41 } \\
\text { Mean }\end{array}$ & $\begin{array}{l}4.20 \\
3.83\end{array}$ & & & & & $\mathrm{e}$ & $\begin{array}{l}3.10 \\
3.13\end{array}$ & & & c & d & $\mathrm{e}$ & $\mathrm{f}$ & $\mathrm{g}$ & $\begin{array}{r}3.40 \\
249.40\end{array}$ & & & & & \\
\hline
\end{tabular}

Means within a column followed by different letters are significantly different $(\mathrm{P}<0.05)$ according to the StudentNewman-Keuls multiple range test. 
Table S8. Pearson linear correlation coefficients between descriptors studied ( $\mathrm{C}$ codes) according to the Bonferroni test (P $\leq 0.05 ; \mathrm{r} \geq 0.78$ ).

Horizontal and vertical lines separate correlations corresponding to descriptors from the same part of the plant (above) from those corresponding to correlations between descriptors from different parts of the plant (below). Significant values are represented in bold.

\begin{tabular}{|c|c|c|c|c|c|c|c|c|c|c|c|c|c|c|c|c|c|c|c|c|}
\hline & C1 & $\mathrm{C} 2$ & C3 & C4 & C5 & C6 & C7 & C8 & C9 & C10 & C11 & $\mathrm{C} 12$ & C13 & C14 & C15 & C16 & C17 & $\mathrm{C} 18$ & C19 & $\mathrm{C} 20$ \\
\hline C1 & 1.00 & & & & & & & & & & & & & & & & & & & \\
\hline C2 & 0.35 & 1.00 & & & & & & & & & & & & & & & & & & \\
\hline C3 & 0.36 & 0.38 & 1.00 & & & & & & & & & & & & & & & & & \\
\hline $\mathrm{C} 4$ & -0.11 & 0.55 & 0.22 & 1.00 & & & & & & & & & & & & & & & & \\
\hline C5 & 0.04 & 0.33 & 0.19 & 0.46 & 1.00 & & & & & & & & & & & & & & & \\
\hline C6 & 0.49 & 0.32 & 0.24 & -0.28 & -0.23 & 1.00 & & & & & & & & & & & & & & \\
\hline C7 & 0.45 & 0.37 & 0.31 & -0.10 & 0.18 & 0.84 & 1.00 & & & & & & & & & & & & & \\
\hline C8 & 0.42 & 0.35 & 0.36 & 0.13 & 0.51 & 0.56 & 0.90 & 1.00 & & & & & & & & & & & & \\
\hline C9 & 0.51 & 0.45 & 0.44 & 0.29 & 0.56 & 0.27 & 0.56 & 0.74 & 1.00 & & & & & & & & & & & \\
\hline $\mathrm{C} 10$ & 0.50 & 0.20 & 0.23 & -0.26 & -0.28 & 0.82 & 0.82 & 0.62 & 0.32 & 1.00 & & & & & & & & & & \\
\hline C11 & 0.01 & 0.12 & 0.10 & 0.28 & -0.16 & -0.08 & -0.10 & -0.03 & 0.15 & 0.11 & 1.00 & & & & & & & & & \\
\hline $\mathrm{C} 12$ & 0.38 & 0.31 & 0.23 & -0.09 & -0.44 & 0.61 & 0.40 & 0.16 & 0.12 & 0.69 & 0.56 & 1.00 & & & & & & & & \\
\hline C13 & 0.29 & 0.22 & 0.19 & -0.03 & -0.44 & 0.43 & 0.25 & 0.10 & 0.13 & 0.57 & 0.78 & 0.93 & 1.00 & & & & & & & \\
\hline C14 & 0.22 & 0.21 & 0.12 & 0.03 & -0.43 & 0.34 & 0.17 & 0.05 & 0.11 & 0.51 & 0.84 & 0.89 & 0.98 & 1.00 & & & & & & \\
\hline C15 & 0.07 & 0.17 & 0.05 & -0.05 & -0.45 & 0.25 & 0.07 & -0.05 & 0.06 & 0.35 & 0.82 & 0.74 & 0.86 & 0.91 & 1.00 & & & & & \\
\hline C16 & 0.38 & 0.30 & 0.14 & -0.11 & -0.37 & 0.57 & 0.42 & 0.22 & 0.21 & 0.68 & 0.47 & 0.84 & 0.84 & 0.81 & 0.70 & 1.00 & & & & \\
\hline C17 & 0.19 & 0.28 & -0.03 & 0.12 & -0.45 & 0.13 & 0.03 & -0.11 & -0.05 & 0.42 & 0.44 & 0.59 & 0.58 & 0.62 & 0.55 & 0.38 & 1.00 & & & \\
\hline C18 & -0.05 & -0.46 & -0.25 & -0.28 & 0.05 & -0.19 & 0.01 & 0.14 & 0.10 & -0.01 & 0.13 & -0.23 & -0.08 & -0.07 & -0.06 & -0.13 & -0.26 & 1.00 & & \\
\hline C19 & -0.06 & -0.41 & -0.29 & -0.19 & -0.06 & -0.18 & -0.07 & 0.03 & 0.09 & -0.04 & 0.13 & -0.13 & -0.04 & -0.01 & 0.01 & -0.17 & -0.09 & 0.84 & 1.00 & \\
\hline C20 & -0.06 & -0.39 & -0.04 & -0.50 & -0.15 & -0.11 & -0.01 & 0.03 & 0.01 & 0.07 & 0.05 & -0.14 & 0.01 & -0.01 & 0.11 & 0.01 & -0.10 & 0.65 & 0.46 & 1.00 \\
\hline C21 & 0.12 & -0.33 & 0.10 & -0.20 & 0.28 & -0.07 & 0.16 & 0.32 & 0.31 & 0.16 & 0.12 & -0.10 & 0.02 & 0.02 & -0.11 & 0.06 & -0.21 & 0.54 & 0.22 & 0.45 \\
\hline C22 & 0.33 & 0.03 & 0.22 & -0.08 & -0.28 & 0.48 & 0.40 & 0.28 & 0.36 & 0.50 & 0.22 & 0.44 & 0.43 & 0.39 & 0.26 & 0.42 & 0.27 & 0.12 & 0.14 & 0.04 \\
\hline C23 & 0.13 & -0.29 & 0.16 & -0.16 & 0.28 & -0.06 & 0.17 & 0.33 & 0.34 & 0.18 & 0.12 & -0.08 & 0.04 & 0.03 & -0.11 & 0.07 & -0.19 & 0.52 & 0.19 & 0.43 \\
\hline C24 & -0.14 & -0.34 & 0.02 & -0.23 & -0.04 & 0.16 & 0.30 & 0.35 & 0.14 & 0.27 & 0.08 & -0.02 & 0.04 & 0.09 & 0.14 & -0.01 & -0.15 & 0.42 & 0.51 & 0.26 \\
\hline C25 & -0.33 & -0.41 & -0.22 & -0.23 & 0.18 & -0.41 & -0.27 & -0.15 & -0.18 & -0.37 & -0.10 & -0.58 & -0.45 & -0.41 & -0.25 & -0.49 & -0.32 & 0.61 & 0.40 & 0.50 \\
\hline C26 & 0.14 & 0.68 & -0.04 & 0.29 & 0.24 & 0.13 & 0.01 & -0.08 & 0.01 & -0.10 & -0.13 & 0.17 & 0.00 & 0.02 & 0.03 & 0.13 & 0.16 & -0.65 & -0.52 & 0.52 \\
\hline C27 & 0.05 & 0.05 & -0.23 & -0.04 & 0.46 & -0.06 & 0.09 & 0.23 & 0.22 & -0.22 & -0.27 & -0.44 & -0.39 & -0.41 & -0.30 & -0.18 & -0.61 & 0.43 & 0.30 & 0.32 \\
\hline C28 & 0.13 & 0.66 & 0.03 & 0.27 & 0.06 & 0.20 & 0.01 & -0.14 & -0.07 & 0.02 & -0.05 & 0.33 & 0.14 & 0.16 & 0.14 & 0.21 & 0.37 & -0.78 & -0.64 & \\
\hline
\end{tabular}

\section{CORRELATIONS BETWEEN DESCRIPTORS.}

Table S8. Continued.

\begin{tabular}{|c|c|c|c|c|c|c|c|c|c|c|c|c|c|c|c|c|c|c|c|}
\hline & C21 & $\mathrm{C} 22$ & $\mathrm{C} 23$ & C24 & $\mathrm{C} 25$ & C26 & C27 & C28 & C29 & C30 & C31 & C32 & C33 & C34 & C35 & C36 & C37 & C38 & C39 \\
\hline $\mathrm{C} 21$ & 1.00 & & & & & & & & & & & & & & & & & & \\
\hline $\mathrm{C} 22$ & 0.24 & 1.00 & & & & & & & & & & & & & & & & & \\
\hline $\mathrm{C} 23$ & 0.97 & 0.28 & 1.00 & & & & & & & & & & & & & & & & \\
\hline C24 & 0.21 & 0.25 & 0.19 & 1.00 & & & & & & & & & & & & & & & \\
\hline $\mathrm{C} 25$ & 0.38 & -0.18 & 0.36 & 0.19 & 1.00 & & & & & & & & & & & & & & \\
\hline $\mathrm{C} 26$ & -0.46 & $\begin{array}{c}-0.39 \\
\end{array}$ & -0.47 & -0.55 & -0.41 & 1.00 & & & & & & & & & & & & & \\
\hline C27 & 0.06 & -0.42 & 0.03 & 0.09 & 0.32 & 0.12 & 1.00 & & & & & & & & & & & & \\
\hline C28 & -0.49 & -0.24 & -0.48 & -0.57 & -0.51 & 0.94 & -0.21 & 1.00 & & & & & & & & & & & \\
\hline C29 & 0.18 & 0.45 & 0.20 & 0.36 & -0.10 & -0.78 & -0.26 & -0.68 & 1.00 & & & & & & & & & & \\
\hline C30 & 0.28 & 0.41 & 0.29 & 0.50 & 0.04 & -0.82 & -0.17 & -0.76 & 0.96 & 1.00 & & & & & & & & & \\
\hline C31 & 0.19 & 0.23 & 0.19 & 0.49 & -0.02 & -0.56 & -0.13 & -0.51 & 0.63 & 0.63 & 1.00 & & & & & & & & \\
\hline C 32 & 0.25 & 0.69 & 0.28 & 0.39 & -0.20 & -0.67 & -0.38 & -0.51 & 0.84 & 0.82 & 0.53 & 1.00 & & & & & & & \\
\hline C33 & 0.35 & 0.33 & 0.34 & 0.30 & 0.07 & -0.35 & 0.00 & -0.30 & 0.27 & 0.32 & 0.32 & 0.64 & 1.00 & & & & & & \\
\hline C34 & 0.21 & 0.65 & 0.24 & 0.35 & -0.23 & -0.68 & -0.44 & -0.51 & 0.88 & 0.84 & 0.59 & 0.98 & 0.57 & 1.00 & & & & & \\
\hline C 35 & -0.02 & -0.33 & -0.03 & 0.06 & 0.23 & -0.34 & 0.20 & -0.44 & 0.40 & 0.40 & 0.25 & -0.15 & -0.59 & -0.05 & 1.00 & & & & \\
\hline C36 & -0.37 & 0.17 & -0.34 & -0.47 & -0.60 & 0.19 & -0.36 & 0.32 & 0.19 & -0.08 & 0.06 & 0.17 & -0.15 & 0.22 & -0.03 & 1.00 & & & \\
\hline C37 & -0.29 & 0.19 & -0.28 & 0.19 & -0.49 & 0.34 & -0.16 & 0.39 & 0.01 & -0.07 & 0.11 & 0.09 & -0.02 & 0.06 & -0.22 & 0.29 & 1.00 & & \\
\hline C38 & -0.06 & 0.15 & -0.06 & 0.43 & -0.18 & 0.05 & 0.06 & 0.02 & 0.08 & 0.06 & 0.19 & 0.03 & -0.16 & -0.01 & 0.09 & 0.12 & 0.82 & 1.00 & \\
\hline C39 & 0.29 & 0.38 & 0.30 & 0.29 & -0.06 & -0.70 & -0.18 & -0.61 & 0.78 & 0.77 & 0.55 & 0.85 & 0.65 & 0.87 & -0.02 & 0.05 & -0.33 & -0.36 & 1.00 \\
\hline
\end{tabular}




\begin{tabular}{|c|c|c|c|c|c|c|c|c|c|c|c|c|c|c|c|c|c|c|c|c|}
\hline C29 & 0.03 & -0.41 & 0.12 & -0.10 & -0.45 & -0.06 & -0.01 & 0.01 & 0.05 & 0.23 & 0.31 & 0.15 & 0.31 & 0.29 & 0.23 & 0.25 & 0.13 & 0.37 & 0.34 & $\begin{array}{l}0.61 \\
0.32\end{array}$ \\
\hline C30 & -0.04 & -0.46 & 0.08 & -0.14 & -0.38 & -0.08 & 0.02 & 0.07 & 0.04 & 0.22 & 0.33 & 0.10 & 0.27 & 0.26 & 0.22 & 0.19 & 0.05 & 0.51 & 0.44 & 0.41 \\
\hline C31 & -0.10 & -0.32 & 0.15 & -0.25 & -0.19 & 0.05 & 0.20 & 0.21 & 0.13 & 0.34 & -0.10 & 0.00 & 0.05 & 0.00 & -0.04 & 0.11 & 0.03 & 0.18 & 0.22 & 0.38 \\
\hline C 32 & 0.32 & -0.26 & 0.27 & -0.28 & -0.52 & 0.40 & 0.35 & 0.24 & 0.17 & 0.59 & 0.22 & 0.41 & 0.45 & 0.40 & 0.29 & 0.46 & 0.20 & 0.23 & 0.18 & 0.24 \\
\hline C 33 & 0.44 & -0.14 & 0.25 & -0.54 & -0.27 & 0.61 & 0.54 & 0.39 & 0.10 & 0.63 & -0.13 & 0.23 & 0.18 & 0.12 & 0.06 & 0.37 & -0.07 & 0.13 & -0.11 & 0.32 \\
\hline C34 & 0.21 & -0.35 & 0.24 & -0.29 & -0.58 & 0.31 & 0.23 & 0.11 & 0.05 & 0.50 & 0.20 & 0.37 & 0.42 & 0.37 & 0.25 & 0.42 & 0.17 & 0.17 & 0.13 & 0.22 \\
\hline C35 & -0.49 & -0.33 & -0.23 & 0.31 & 0.12 & -0.81 & -0.62 & -0.35 & -0.13 & -0.61 & 0.20 & -0.47 & -0.23 & -0.19 & -0.12 & -0.39 & -0.16 & 0.36 & 0.39 & 0.21 \\
\hline C36 & 0.25 & 0.24 & 0.13 & 0.17 & -0.31 & 0.10 & -0.07 & -0.17 & 0.06 & 0.13 & -0.03 & 0.26 & 0.22 & 0.19 & 0.11 & 0.29 & 0.33 & -0.53 & -0.38 & 0.35 \\
\hline C37 & 0.02 & 0.55 & 0.18 & 0.22 & -0.14 & 0.38 & 0.31 & 0.20 & 0.23 & 0.41 & 0.40 & 0.59 & 0.60 & 0.63 & 0.64 & 0.64 & 0.41 & -0.39 & -0.23 & 0.19 \\
\hline C38 & -0.08 & 0.34 & 0.11 & 0.24 & 0.06 & 0.10 & 0.20 & 0.24 & 0.29 & 0.21 & 0.31 & 0.23 & 0.33 & 0.38 & 0.42 & 0.34 & 0.21 & 0.00 & 0.16 & $\begin{array}{l}0.19 \\
0.09\end{array}$ \\
\hline C39 & 0.23 & -0.49 & 0.21 & -0.39 & -0.39 & 0.21 & 0.21 & 0.15 & 0.03 & 0.36 & -0.09 & 0.08 & 0.09 & 0.01 & -0.09 & 0.16 & -0.13 & 0.28 & 0.15 & 0.27 \\
\hline
\end{tabular}

